\title{
Schmidt Hammer exposure dating (SHED): Establishment and implications for the retreat of the last British Ice Sheet
}

DOI:

10.1016/j.quageo.2016.02.002

Document Version

Accepted author manuscript

Link to publication record in Manchester Research Explorer

\section{Citation for published version (APA):}

Tomkins, M., Dortch, J., \& Hughes, P. (2016). Schmidt Hammer exposure dating (SHED): Establishment and implications for the retreat of the last British lce Sheet. Quaternary Geochronology, 33(46-60), 46-60.

https://doi.org/10.1016/j.quageo.2016.02.002

\section{Published in:}

Quaternary Geochronology

\section{Citing this paper}

Please note that where the full-text provided on Manchester Research Explorer is the Author Accepted Manuscript or Proof version this may differ from the final Published version. If citing, it is advised that you check and use the publisher's definitive version.

\section{General rights}

Copyright and moral rights for the publications made accessible in the Research Explorer are retained by the authors and/or other copyright owners and it is a condition of accessing publications that users recognise and abide by the legal requirements associated with these rights.

\section{Takedown policy}

If you believe that this document breaches copyright please refer to the University of Manchester's Takedown Procedures [http://man.ac.uk/04Y6Bo] or contact uml.scholarlycommunications@manchester.ac.uk providing relevant details, so we can investigate your claim.

\section{OPEN ACCESS}




\title{
Schmidt Hammer exposure dating (SHED): Establishment and implications for the retreat of the last British Ice Sheet
}

\author{
M.D. Tomkins ${ }^{\text {a }}$,J.M. Dortch ${ }^{a^{*}}$, P.D. Hughes ${ }^{a}$ \\ a Department of Geography, School of Environment, Education and Development, \\ University of Manchester, Cryosphere Research At Manchester, M13 9PL Manchester, \\ United Kingdom
}

Corresponding author: Jason.Dortch@manchester.ac.uk (J.M. Dortch)

\author{
Keywords: \\ British Ice Sheet \\ TCN dating \\ Schmidt hammer exposure dating \\ Glacial chronology
}

\begin{abstract}
Ninety-eight surfaces related to the retreat of the British Ice Sheet (BIS) and dated using Terrestrial Cosmogenic Nuclide Dating (TCND) were sampled using the Schmidt Hammer to expand on relative dating techniques and establish Schmidt Hammer exposure dating (SHED) as an effective method for dating glacial landforms in the UK. The BIS is an effective analogue for contemporary glacial systems but our understanding of its retreat under changing climate conditions is constrained by a limited number of dates obtained from existing methods $\left({ }^{14} \mathrm{C}\right.$, OSL). These methods are restricted in their application to glacial environments and while TCND has addressed this to some degree, its cost and potential for outliers encourage the establishment of new techniques. SHED fulfils this requirement by providing a cost-efficient method for obtaining numerous direct ages that are of comparable accuracy and precision to TCND. A multi-lithology approach has established that many rock types are unsuitable for numerical dating. However, a robust calibration curve was generated $\left(\mathrm{R}^{2}=0.81, p=<0.01\right)$ for granite surfaces and applied to 31 undated granite erratics on Shap Fell, NW England. SHED indicates that BIS retreat occurred at $16.5 \pm 0.5 \mathrm{ka}$, a conclusion which supports our current understanding of regional deglaciation and indicates that SHED can be a valuable and cost-effective geochronological tool.
\end{abstract}

\section{Introduction}

The British Ice Sheet (BIS), which reached it maximum extent by $27 \mathrm{ka}$ (Sejrup et al., 2005), is of particular importance as an analogue for contemporary glacial systems (Clark et al., 2012). Our understanding of BIS extent is relatively robust (Figure 1) as recent research (Sejrup et al., 
2005; Bradwell et al., 2009b) has demonstrated the persistence of extensive off-shore ice cover and the extension of the Fennoscandian Ice Sheet across the North Sea as first reconstructed by Geikie (1894) and Croll (1875) respectively. However, due to limited direct evidence for these early assessments (Clark et al., 2012), most reconstructions proposed that off-shore ice was extremely restricted, an assessment popularised by Bowen et al., (1986), although this has been challenged by recent research (e.g. Scourse et al., 2009; Ballantyne, 2010). BIS retreat was highly dynamic and spatially variable, as retreat fundamentally shifted from marine to terrestrial terminating margins (Clark et al., 2012) and was punctuated by major readvance events (Boulton et al., 2002). As such, the geomorphological record is highly fragmented as ice expansion during readvance events such as the Wester Ross Readvance (WRR) (Ballantyne et al., 2009a) and Loch Lomond Stadial (LLS) (Golledge, 2010) reworked and removed previous evidence of BIS retreat; thus preventing the straightforward coupling of glacial and climatic records. Even though climatic datasets are available, of sufficient resolution, and cover an appropriate timespan to facilitate analysis of the geomorphological record (e.g. Lowe et al., 2008), robust comparison is not possible without precise and accurate geochronometric dating to constrain the nature and timing of BIS deglaciation.

In response to this, many relative and radiometric dating methods have been used to form the basis for reconstructions of BIS retreat (Ballantyne, 2010; Chiverrell and Thomas, 2010; Clark et al., 2012). The broad agreement of these studies suggests that they are relatively robust assessments, although the research community is not without disagreement (Bowen et al., 2002). While the number of dated landforms is increasing (cf. A. Hughes et al., 2011), it is clear that further dating is still necessary (Ballantyne, 2010) as many sites remain undated and our understanding of retreat is often based on a limited number of samples using methods which can produce erroneous or uncertain results. It is clear that the limitations of existing methods must be addressed and new methods developed to better reconstruct past events and further constrain glacial response times.

The primary method for dating glacial retreat is Terrestrial Cosmogenic Nuclide Dating (TCND) which measures rock surface exhumation based on the spallation of upper atmospheric cosmic rays, which fragment target elements (Balco, 2011) and form radioactive isotopes (Briner, 2011). The application of TCND to boulders deposited on moraines (e.g. Everest et al., 2006; Dortch et al., 2010a; Wilson et al., 2013b) and bedrock surfaces (e.g. Stone et al., 1998; Dortch et al., 2010a,b; Glasser et al., 2012; Hughes et al., 2016) can provide a direct age for glacial landforms. Despite the widespread application of this technique (Cockburn and Summerfield, 2004), there are numerous sources of error in calculating TCN exposure ages and many methodological uncertainties which are still to be addressed (Applegate et al., 2012; Mackey and Lamb, 2013, Owen and Dortch 2014). In particular, nuclide production rate variation due to altitude and latitude necessitates the use of scaling schemes to calculate site specific production rates. Further research under the CRONUS-Earth Project (Phillips et al., 2015) and the widespread application 
of new exposure age calculators (Marrero et al., 2015) may provide a consistent method for data generation although currently, the choice of appropriate scaling scheme remains uncertain.

The single largest source of uncertainty that leads to scattering of TCN ages is geologic uncertainty (Dortch et al., 2013) which includes processes that affect sample stability (Bursik, 1991), moraine stabilisation (Ivy-Ochs et al., 2008; Dortch et al., 2009), transient or topographic shielding (Dunne et al., 1999), inheritance (Putkonen and Swanson, 2003) and weathering rate variation (Colman, 1981; Sjöberg and Broadbent, 1991). Therefore, although the development and application of TCN dating has been effective in constraining the timing of BIS retreat, it is clear that researchers should be cautious in their interpretation of exposure ages and employ statistical analysis to identify outliers (Hallet \& Putknonen, 1996; Briner et al., 2005; Heyman et al., 2013). The greatest barrier to isolating and correcting many of these uncertainties is the cost of TCN dating, which prevents high sample studies and statistically robust identification and rejection of erroneous results (Dortch et al., 2013). Careful geomorphological analysis and the use of multiple isotopes can go some way to addressing these issues although this timeconsuming approach is not always successful. TCN dating is a powerful geochronological tool but its associated uncertainties necessitate further empirical testing and refining of the method. High cost and limited facility resources demonstrate that the development of cost efficient methods is crucial to augment TCN dating studies in the pursuit of more detailed studies (for example, asynchronous ice sheet lobes).

Moving beyond relative dating, this study will establish Schmidt hammer exposure dating (SHED) as an effective method for numerical dating of glacial landforms in the UK by adopting a multi-site and multi-lithology calibration using TCN exposure ages. A lithology specific calibration curve is extended beyond $20 \mathrm{ka}$ and applied to undated surfaces in a region well dated using other methods to demonstrate the validity of SHED. By combining a methodological and practical approach, this study not only provides the foundation for further application of SHED but can test and validate geomorphological interpretations and further our understanding of BIS retreat. Ultimately, we show that SHED can provide a direct age for glacial landforms and is of comparable accuracy and precision to TCN dating while providing immediate and cost efficient results.

\section{Study area}

TCN dated surfaces were identified and sampled based on 11 published articles, with 89 samples located in Scotland, the majority of these north of the Cairngorms including samples from Skye, Torridon and the Orkneys, Scotland. Two further sampling sites are located on Shap Fell, NW England and on the Aran Ridge, N Wales (Figure 1). Although climatic variation is evident between these regions, particularly for the drier sites in North East Scotland, the majority of sites are typically wet, often in excess of $>3000 \mathrm{~mm} / \mathrm{yr}$ and certainly greater than $2000 \mathrm{~mm} / \mathrm{yr}$ (Met Office, 2015). Samples were obtained from a range of depositional and erosional environments 
including moraines, roches moutonnées and summit and corrie blockfields, with contrasting topographic settings, between $21 \mathrm{~m}$ a.s.l. in Slapin Bay, Skye (Small et al., 2012) to 928m a.s.l. on Maol Chean Dearg, Torridon (Fabel et al., 2012). Topographic variation may play a key role in localised precipitation (Ballantyne, 1983; Brundson et al., 2001). The use of a statistically large dataset is necessary to analyse whether SHED can be applied in regions of similar climate or identify whether local climatic and topographic settings result in non-linear weathering over regional spatial scales. Sampling was focused on five lithologies; granite, sandstones, gneiss quartz and Ordovician felsic ash-flow tuffs. Adopting a multi-lithology and multi-landform approach is of particular value as this study is the first attempt to establish SHED in the UK.

\section{Methods}

\subsection{Review of Schmidt Hammer methods}

The ' $\mathrm{N}$ ' type Schmidt hammer employed in this study was first applied to glacial environments in the 1960s (Goudie, 2006) and records a rebound value ( $\mathrm{R}$ Value), a measure of how far a piston rebounds after being fired at a surface. Harder rocks will result in higher $\mathrm{R}$ values (Aydin and Basu, 2005). The use of the Schmidt Hammer as a relative dating tool was established by Matthews and Shakesby (1984) and is based on the principle that surfaces which have been uncovered for longer periods of time will be relatively softer than surfaces which have been uncovered recently. Relative dating has been largely limited to Holocene surfaces (e.g. Evans $e t$ al., 1999; Shakesby et al., 2011; Rode and Kellerer-Pirklbauer, 2012) with only a few attempts to extent the method beyond $10 \mathrm{ka}$. This restricted scope is of little value from the perspective of studying the BIS as retreat pre-dates the Holocene.

Lithology is an important precursor to Schmidt hammer testing as variance between weak and strong lithologies is highly significant (Selby, 1993). Given the importance of lithology in determining $\mathrm{R}$ values, relative dating can only be applied to single lithologies (Winkler, 2005) and has been limited to single site studies (valley - mountain range scale), as variation in climate may drive changes in physical and chemical weathering rates and result in non-linearity over larger spatial scales. The technique is relatively precise, able to differentiate between deposits at $\pm 300 \mathrm{yr}$ (Matthews and Shakesby, 1984; McCarroll, 1987) and up to $\pm 100 \mathrm{yr}$ intervals (Evans et al., 1999).

However, the Schmidt Hammer is sensitive to surface discontinuities and rock moisture (Sumner $\&$ Nel, 2002) and surface moisture content (Viles et al., 2011). Rock moisture is unlikely to have a significant impact within the confines of this study due to the ubiquitous $>2000 \mathrm{~mm} / \mathrm{yr}$ precipitation rates, as the 2-10 point $R$ value variation identified by Sumner and Nel (2002) was between 'oven dry' and 'fully saturated' samples. The variation in the highly precipitous mountainous regions of the UK is unlikely to be as significant. However, surface moisture content may be of greater significance as it can alternate stochastically within short timescales and can result in an observable difference in $\mathrm{R}$ values (Viles et al., 2011). 
To avoid anomalous results, procedures as outlined by Viles et al., (2011) must be followed. The Schmidt hammer should be used perpendicular to the surface (Aydin, 2015), avoiding rough, irregular (Williams and Robinson, 1983) and lichen covered surfaces (Matthews and Owen, 2008), which significantly reduce $R$ values, while restricting sampling to horizontal surfaces and blocks of sufficient size, typically in excess of $25 \mathrm{~kg}$ (Sumner and Nel, 2002; Demirdag et al., 2009). However, there are contentious issues, particularly in regards to operator variance, deemed insignificant by Day and Goudie (1977). In contrast, Viles et al., (2011) show that R value variation between researchers for the original ' $N$ ' type Schmidt Hammer can be significant but varies before $(p=0.00)$ but not after $(p=0.10)$ carborundum treatment, which removes surface irregularities. However, variation in this test was highly influenced by significantly higher readings by one operator (Viles et al., 2011). In this study, all surfaces were sampled by one author (Tomkins) and therefore results are internally consistent. Clearly, further work on the impacts of operator variance needs to be undertaken.

Additionally, there is no consensus on how many $\mathrm{R}$ values are necessary on each surface (Table1; Goktan and Gunes, 2005). Given the sensitivity of the tool to surface discontinuities, moisture content and surface texture, a sufficiently large dataset, typically greater than $25 \mathrm{R}$ Values for weak and moderately strong rocks (Selby, 1980) is necessary to permit rapid identification of anomalous results (Shakesby et al., 2006). We follow the methods of Niedzielski et al., (2009) who provide statistical analysis for 14 key lithologies and show that the minimum sample size requirement varies significantly between lithologies. For this study, $30 \mathrm{R}$ values were recorded for each sampled surface, irrespective of lithology, as this ensured that even coarse surfaces generated statistically significant results and eliminates the need for carborundum surface preparation while removal of the lowest values was not undertaken as this "produces different effects and is generally not recommended" (Niedzielski et al. 2009).

\subsection{Schmidt hammer exposure dating (SHED)}

SHED has been undertaken in New Zealand (Winkler, 2009; Stahl et al., 2013), Portugal (Sánchez et al., 2009) and Norway (Matthew and Owen, 2010; Matthews and Winkler, 2011) and requires independent dating controls to generate $\mathrm{R}$ value calibration curves. These previous studies have used a limited number $(n=9)$ of TCN exposure ages as calibration points (Winkler, 2009) while Matthews and Owen (2010) based their calibration on two control points, one dated to the Little Ice Age at $100 \pm 50 \mathrm{yr}$ based on lichenometry (Matthews, 2005) and the other dated to $9700 \mathrm{yr}$ based on ${ }^{14} \mathrm{C}$ (Dahl et al., 2002; Matthews \& Dresser, 2008). This study adopts and advocates a different approach by sampling many TCN dated surfaces from published research in order to develop a robust calibration curve (Table-2).

The majority of previous studies focus solely on the Holocene, although the study by Sánchez et al., (2009) sampled surfaces beyond $100 \mathrm{ka}$. White and Brantley (2003) suggest that weathering 
rates decline exponentially through time, thus glacial boulders from Holocene deglaciation would exhibit significantly lower R values compared to surfaces recently uncovered (< $100 \mathrm{yr})$. Although the $\mathrm{R}$ value difference between 10-20 or 90-100 ka surfaces is likely to be of lesser magnitude, Sánchez et al., (2009) suggest that Schmidt Hammer methods may be applicable to surfaces beyond $100 \mathrm{ka}$. SHED can be of higher precision than TCN dating (Matthews and Owen, 2010) although it is not yet clear if this will be observed beyond the Holocene. Moreover, the precision of SHED will be, in part, limited by the precision of the technique used to develop the calibration curve.

\subsection{Sampling Procedure}

$\mathrm{R}$ values were collected for the following lithologies: granite $(n=38)$, sandstone $(n=36)$, gneiss $(n=10)$, quartz $(n=9)$ and Ordovician felsic ash-flow tuffs $(n=5)$. Sampling was limited to sites in which 2 or more surfaces had been dated as this ensured anomalous results could be more easily identified. Additionally, sampling was restricted to dates generated using Beryllium 10 $\left({ }^{10} \mathrm{Be}\right)$, the most commonly used isotope due to its straightforward decay chain.

A further 31 surfaces dated using Chlorine $36\left({ }^{36} \mathrm{Cl}\right)$ were sampled (Vincent et al., 2010; Ballantyne et al., 2009b; Wilson et al., 2013b) but are not considered in this study as many of the surfaces, in particular those dated by Ballantyne et al., (2009b) and Wilson et al., (2013b), may be compromised by inheritance. Although the remaining ${ }^{36} \mathrm{Cl}$ surfaces (Vincent et al., 2010) conform to our current understanding of regional deglaciation (Clark et al., 2012), significant variation between scaling schemes for this isotope is possible, often in excess of 50\% (Schimmelpfennig et al., 2009) due to minor discrepancies in the calibration process (Swanson and Caffee, 2001, Licciardi et al., 2008). Given the potential for these errors, ${ }^{36} \mathrm{Cl}$ samples are not included in this analysis but will be considered in future. As a result, three ${ }^{10} \mathrm{Be}$ surfaces from P. Hughes et al. (2012) and Wilson et al., (2013b) are not included in the analysis.

Dated surfaces were located using maps from published papers, GPS data and sample photographs provided by researchers. However, some incorrect surfaces may have been sampled due to inaccurate GPS data recorded during the 1990s. The GPS Selective Availability (SA) feature, disabled in 2000, intentionally degraded civilian GPS accuracy by up to $100 \mathrm{~m}$. To compensate for this, the largest erratics which showed no sign of instability and were sufficiently removed from any nearby cliff faces were selected. Sampling surfaces in the correct location and from the correct lithology should be representative of the dated sample. In many cases, it was possible to identify direct evidence of sampling (Figure 2, particularly for Torridonian Sandstone surfaces where lichen growth was slowest (Ballantyne et al., 2009a), but for other lithologies this was only possible for recent research (Kirkbride et al., 2014).

\section{4. $R$ value and Age calibration}


Having generated over 10,000 R values, the Schmidt Hammer may have lost condition (Goudie, 2006). Testing of a specific Sandstone boulder at the start and end of sampling indicated a four point difference (June 2013, $48.08 \pm 0.82$ - December 2014, $44 \pm 1.05$ ). The data were compiled chronologically and thus, it was possible to calibrate each individual $\mathrm{R}$ value to correct for temporal changes in spring tension. It was assumed that the tool deteriorated linearly through time which yields an average reduction per $\mathrm{R}$ value of $0.00083 \%$.

The CRONUS Earth Calculator (Balco et al. 2008) was used to recalculate all ${ }^{10} \mathrm{Be}$ ages with reference to the Loch Lomond Local Production Rate (LL LPR) (Fabel, D., pers. comm. 2014) which is based on ${ }^{10} \mathrm{Be}$ concentration in samples from boulders on a Younger Dryas moraine and independently constrained by ${ }^{14} \mathrm{C}$ (Fabel et al., 2012). This production rate $(3.92 \pm 0.18)$ minimises scaling uncertainties that are present in global scaling schemes (Balco, 2011). Although other local production rates are available, including the North West Highlands LPRs (NWH) of Ballantyne and Stone (2012), these have not been independently dated and assume retreat of Younger Dryas glaciers between 11.6-12.2 ka based on rapid warming observed in climate records (Brooks and Birks, 2000; Brooks et al., 2012) at the onset of the Holocene. Ages referred to in this study are based on the St time-independent scheme (Lal, 1991; Stone, 2000) assuming $0 \mathrm{~mm}$ erosion. Recalibrated LL LPR ages are on average $14.3 \%$ older than ages based on global production rates.

\subsection{Incomplete/incorrect data}

Samples from Stone et al., (1998), Everest and Kubik (2006) and Bradwell et al., (2008b) did not incorporate or provide data for topographic shielding. Values were generated using a python code developed by Li (2013) based on an OS Terrain 50 DTM available from Edina Digimap and calculated using ArcGIS, with an azimuth interval of $10^{\circ}$ and elevation interval of $5^{\circ}$. Additionally, some studies did not include reference to sample density or thickness. The latter was assumed to be 5cm (Darvill, 2013) as below this, cosmogenic nuclide concentrations rapidly decrease and nuclide production is quickly dominated by muonic reactions rather than nucleonic spallation (Gosse and Phillips, 2001). For sample density, lithology specific values from other publications were used although exposure ages are unlikely to change significantly due to these variables. Granitic rocks from Glen Eaniach (Everest and Kubik 2006) were assumed to be $2.7 \mathrm{~g}$ $\mathrm{cm}^{-3}$ based on the values in nearby Coire an Lochain (Kirkbride et al., 2014) while Sandstone bedrock from An Teallach (Stone et al., 1998) was assumed to be $2.6 \mathrm{~g} \mathrm{~cm}^{-3}$ based on the bedrock densities inferred by Ballantyne et al., (2009a) near the Redpoint and Gairloch moraines. For Gneissic boulders on the Wester Ross peninsula, dated by Everest et al., (2006), the nearest analogue is those found on the Orkneys by Phillips et al., (2008), and the density of these samples, at $2.4 \mathrm{~g} \mathrm{~cm}^{-3}$ is applied here.

The CRONUS Earth recalibrated age for SHAP-03 $(20.05 \pm 1.15 \mathrm{ka})$ may be inaccurate. LL LPR ages are typically 6.8-7\% older than exposure ages derived from the North West Highlands 11.6 ka LPR (Ballantyne et al., 2014), which SHAP-03 is significantly older (13.4\%). Additionally, 
NWH 12.2 LPR and LL LPR ages are almost identical (Ballantyne, C., pers. comm. 2014). This is observed for the other SHAP samples (Maximum difference of $0.4 \%$ ). The $8.2 \%$ increase for SHAP-03 is therefore a major anomaly. This error is unlikely to be associated with CRONUS

Earth as it would be observed for all samples. Therefore, it is suggested that the ${ }^{10} \mathrm{Be}$ concentration may have been reported incorrectly. To address this, SHAP-03 has been calibrated by dividing the reported age by the NWH 11.9 production rate (4.09) and multiplying by the new production rate for the LL LPR (3.92) to generate an age of $18.78 \pm 0.9 \mathrm{ka}$ (Ballantyne, C., pers. comm. 2014). The increase from NWH 11.6 to LL LPR (6.1\%) is in better agreement with Ballantyne et al., (2014) although does differ more from the NWH 12.2 age (1.2\%) than the other SHAP samples. Unfortunately, it is not possible to generate accurate uncertainties using this method, so the original uncertainty as reported by Wilson et al., (2013c) is used. As such, rigorous calibration using the CRONUS Earth calculator is the recommended method for ${ }^{10} \mathrm{Be}$ age calibration.

\subsection{Rejection of young/old ages}

Of the 98 dated surfaces sampled in this study, 22 samples were not accepted as the results may have been compromised by inheritance $(n=6)$, overturning $(n=3)$, transient shielding or site disturbance $(n=4)$ or when Schmidt hammer testing was incorrectly conducted on unsuitable glacially polished or Quartz rich surfaces $(n=8)$. Additionally, sample WH1 from Phillips et al., (2008) $(19.67 \pm 1.19 \mathrm{ka}, \mathrm{R}$ value: $27.64 \pm 0.48)$ was not included in the sandstone lithology regression. This sample was anomalously soft compared to all other sandstones in excess of three standard deviations. The full dataset is presented in Table 1.

\section{Results and discussion}

\section{1. $R$ Value-Exposure Age Relationships}

For many lithologies, the expected age-hardness relationship is not observed (Figure 3, Table 3). Sandstone, quartz, gneiss and Ordovician felsic ash-flow tuff do not have significant correlations, which indicates that 'numerical' dating using the Schmidt Hammer would be of little value. However, a statistically significant relationship is evident for granite surfaces $\left(\mathrm{R}^{2}=\right.$ $0.81, p=<0.01)$ and derived from a statistically acceptable dataset $(n=25)$. In order to test the validity of this calibration, SHED was applied to undated granite surfaces on Shap Fell, NW England with the results compared with other data sources (TCND, OSL) and discussed in the context of our understanding of regional deglaciation. However, before these results are presented, it is necessary to acknowledge some limitations of this study and discuss the suitability of each lithology to SHED.

\subsection{Limitations and Sources of Error}

4.2.1. Age Range 
As this study relies on previously dated surfaces, the application of SHED to Holocene and preLGM deposits is limited. Given the extent of the BIS at its maximum (Bowen et al., 1986, Serjup et al., 2005), pre-LGM deposits are found only in the south-east and tend to be poorly preserved in the landscape (Rose, 2009). Additionally, much of the evidence for pre-LGM glacial stages is inferred from tills (Hamblin et al., 2000), outwash deposits (Rose et al., 2001) and offshore records (Holmes, 1997) which are not often dated using TCND, although studies by Balco and Rovey (2008) and Dehnert and Schlüchter (2008) demonstrate the value of applying this method to sedimentary deposits. However, there have been few attempts to constrain the southern limit of the BIS using this method (Ballantyne, 2010). While there are exposure ages that pre-date the LGM, they are either highly inaccessible (Everest et al., 2013) or have such significant levels of uncertainty (Bowen et al., 2002) that is not clear if they are truly representative of deglaciation. In this study, only seven samples are dated to older than $20 \mathrm{ka}$.

Additionally, no surfaces were sampled which post-date the Loch Lomond Stadial and only five samples were within this interval. This is despite significant evidence for LLS landforms and deposits (Sissons, 1979) although the number of TCN exposure ages related to this glacial readvance is remarkably low. LLS deposits have been dated in Cwm Idwal, North Wales (Phillips et al., 1994), Keskadale, Lake District, (P. Hughes et al., 2012) and in Scotland on Hoy (Ballantyne, 2007a), in the Grampians (Golledge et al., 2007) and Galloway Hills (Ballantyne et al., 2013) and in Coire an Lochain (Kirkbride et al., 2014). However, the vast majority of published TCN exposure ages pre-date the LLS. Of the 160 exposure ages reviewed in Ballantyne (2010), only 9 were directly attributed to the LLS, with 6 further samples from Lough Acorrymore, Ireland (Bowen et al., 2002; Ballantyne et al., 2008b) exhibiting a complex deglaciation history.

Recent publications have attempted to date Holocene glacial advances. In particular, the study by Kirkbride et al., (2014) and its companion piece by Harrison et al., (2014) infer 'Little Ice Age' (Mann et al., 2009) glaciation in the Cairngorms. Further Holocene exposure ages have been reported for rock slope failures (RSF) throughout Scotland (Ballantyne et al., 2014) although less than $1 / 3$ of these are associated with debuttressing during deglaciation. These are the only studies which report accurate Holocene exposure ages in the UK. This contrasts markedly with other SHED studies in Norway (Matthews \& Owen, 2010) and New Zealand (Winkler, 2009) which focus solely on Holocene deposition, and compare very recent deposits $(<0.1 \mathrm{ka})$ with early Holocene landforms. While the age range of this study and the previously mentioned publications is similar $(\sim 10-15 \mathrm{ka})$, the timeframe for that age range is key, given the exponential decline in weathering rates through time (White and Brantley, 2003). This is supported by evidence from Sanchez et al., (2009) and Stahl et al., (2013) as the magnitude of R value reductions decreases through time. While SHED is perhaps most effective at dating recent glacial deposits (< $10 \mathrm{ka}$ ), this study has shown that it can be extended beyond $20 \mathrm{ka}$ for granite surfaces. It is clear that further testing of LLS equivalent and Holocene surfaces in northern 
Europe is a priority for further research, but it is acknowledged that extending this method beyond $25 \mathrm{ka}$ in the UK is unlikely given the extent of the BIS at its maximum. The testing and application of SHED in reasonably well-dated regions (>1800 TCN ages) with multiple glacial cycles $(<400 \mathrm{ka})$ preserved in the landscape (e.g. the Himalaya) is an important step in establishing SHED as a key geochronological tool (Dortch et al., 2013; Owen and Dortch, 2014).

\subsubsection{Cosmogenic Uncertainty}

This study also treats TCN exposure ages as 'absolute ages' but this infers a level of accuracy and precision which is often unwarranted. While samples affected by inheritance, site disturbance, reworking or transient shielding have been omitted, significant errors (1-2 ka) are possible. Thus, some exposure ages used in this study may be challenged by future research. For all dated samples used in this study TCN exposure ages have a mean uncertainty of $\pm 1.3 \mathrm{ka}$. The uncertainty associated with the clustering of ages is typically greater than individual age uncertainties. Significant uncertainty encourages researchers to informally match glacial deposits to high magnitude climatic drivers (Blaauw et al., 2007) but this level of uncertainty is unacceptable for short term glacial events such as the WRR or LLS as the range of uncertainty exceeds the range of the climatic event. While the establishment of LPRs has generated more precise exposure ages, it is not clear if further improvements are possible. While TCND is an effective method for dating glacial landforms, it must be acknowledged that its moderate precision adds an element of uncertainty which is currently difficult to address.

\subsection{Lithological Suitability}

\subsubsection{Granite}

SHED of granitic surfaces is particularly promising as a clear $\mathrm{R}$ value-exposure relationship is evident (Figure 3A), indicating that this lithology weathers linearly over significant spatial scales and for regions of similar climate. Samples are relatively young $(<25 \mathrm{ka})$ and were free from deformities (e.g. cracks). Granite samples were also collected from a range of altitudes (21-928m a.s.1.). Furthermore, the impact of altitude is not evident in our data. For all granite surfaces, there is no $\mathrm{R}$ value-altitude relationship $\left(\mathrm{R}^{2}=0.01, p=0.71\right)$. This contrasts with research by Ballantyne et al., (1998) who found appreciable variation in $\mathrm{R}$ values above and below weathering limits for Torridon sandstone although this perhaps reflects the preservation of the landscape beneath cold-based ice and not R-value variation as a result of enhanced weathering with altitude. However, when 9 high altitude samples (895-928m) from Coire an Lochan (Kirkbride et al., 2014) are removed, a clear relationship is evident $\left(\mathrm{R}^{2}=0.82, p=<0.01\right)$, implying a causal link between $\mathrm{R}$ values and altitude. However, a stronger relationship is observed between sample altitude and deglaciation age $\left(\mathrm{R}^{2}=0.89, \mathrm{p}=<0.01\right)$. As such, this indicates that the potential link between altitude and $\mathrm{R}$ values is simply a function of deglaciation age, as low lying samples underwent deglaciation last, resulting in higher $\mathrm{R}$ values than midaltitude samples, which underwent deglaciation earlier and are proportionally harder. Additionally, although granites may vary in 'base' hardness (Goudie, 2006), e.g. between 
Cairngorm (Brook et al., 2004) and Shap granite (Day and Goudie, 1977), these results suggest that granites are relatively homogenous in texture and mineral assemblage, which leads to timedependent weathering rates which are consistent between granite source areas.

However, not all granites are suitable to SHED. In particular, the quartz-rich pegmatite erratics

in Glen Eaniach (Everest and Kubik, 2006) are not internally consistent $\left(\mathrm{R}^{2}=0.19, p=0.39\right)$ and fit poorly with the established calibration. These surfaces may weather particularly slowly or even non-linearly given the inappropriateness of quartz to SHED.

\subsubsection{Sandstone}

Sampling of sandstone surfaces has shown that there is no relationship between $\mathrm{R}$ values and exposure ages (Figure 3B). Weathering of Sandstone is evident (Turkington \& Paradise, 2005) with time-dependent variation in edge-roundness (Kirkbride \& Bell, 2010) but this clear relationship does not appear to have any appreciable effect on $\mathrm{R}$ values, despite a smooth surface texture and limited lichen colonisation. As there is evidently no link between $\mathrm{R}$ values and exposure ages, Sandstone is clearly not suitable for SHED over large spatial scales. Non-linear weathering of Sandstone surfaces, meso-micro scale variation in weathering processes, or casehardening due to carbonate precipitation must account for some of the $\mathrm{R}$ value variability, as it not explained by any factor considered in this study.

\subsubsection{Quartz}

Surface texture and mineralogical content are key factors in determining the rate and magnitude of rock surface disintegration. In particular, quartz exhibits limited $\mathrm{R}$ value variation (Owen et al., 2007) as it is thermodynamically stable and therefore is particularly resistant to chemical weathering (Figure 3C; Pope, 1995). Additionally, its strong crystalline silicate structure $\left(\mathrm{SiO}_{2}\right)$ ensures that physical weathering occurs at a much slower rate than other minerals, as it is less sensitive to granular disintegration. While it is affected by freeze-thaw cycles (Schwamborn et al., 2012) and does undergo weathering, as the differential lowering of Quartz veins indicates (Owen et al., 2007), it does so slowly that the high magnitude 'noise' generated by the Schmidt Hammer, due to differential surface texture, moisture content, discontinuities or lichen cover, obscures the low magnitude signal from weathering (Figure 3Cc). Moreover, quartzite and quartz veins break down along fractures that can be several centimetres in thickens, which would lead to a stochastic signal in TCND ages and make R Value calibration difficult.

\subsubsection{Gneiss}

The unsuitability of gneiss to SHED (Figure 3D) can be attributed to surface texture. Gneiss is predominantly coarse grained (Feuten et al., 1991) and as the Schmidt Hammer is most effective when applied to flat, planar surfaces (Williams \& Robinson, 1983), it is inferred that the significant $R$ value variation evident in this study (range $=15.1$ ) is representative of the highly variable surface texture and not a function of weathering through time. Gneiss is also highly 
variable in its mineralogical content (Marshak, 2009) and therefore, this lithology is particularly unsuitable, as there is considerable variability both between gneissic surfaces, due to mineralogical content, and on individual surfaces, due to its coarse grained texture.

\subsubsection{Ordovician felsic ash-flow tuffs}

Unfortunately, despite relatively consistent $\mathrm{R}$ values and TCN ages, the data are not internally consistent, indicating that this lithology is unsuitable for SHED numerical dating (Figure 3E). A simple explanation is that the ${ }^{10} \mathrm{Be}$ ages were derived from quartz veins (see Glasser et al., 2012) while $\mathrm{R}$ values were generated from the surrounding bedrock although theoretically, this should have little impact, as the bedrock and quartz veins should have undergone deglaciation concurrently. Another possibility is wide variability in the physical properties of the felsic ashflow tuffs, which also occur in association with intrusive and extrusive rhyolites (Glasser et al., 2012) The sample size for felsic ash-flow tuffs was relatively small $(n=5)$ and recent TCN ages from this and related lithologies has recently become available (Hughes et al., 2016). As new TCN data becomes available, the efficacy of SHED numerical dating on different lithologies can be explored further in the coming years.

\section{Implementing SHED}

\subsection{Case Study}

As a first step to apply the SHED method presented this study, 31 undated Shap granite erratics were sampled from Shap Fell, NW England (Figure 4, Table-4). This site is useful for a number of reasons. Firstly, there are numerous granite erratics derived from the nearby Shap granite pluton (Wilson et al., 2013c). Secondly, it is in region of similar climate but a significant distance from the majority of other tested granite samples in Scotland, thus providing an important testbed for SHED. Thirdly, the region is reasonably well dated with TCN dated samples on Shap Fell (Wilson et al., 2013c) providing direct dates for glacial retreat. OSL dating at New Close and Warton Crag (Telfer et al., 2009) can be used to indicate the commencement of ice free conditions further south. Dating using ${ }^{14} \mathrm{C}$ from Wray Bay (Coope and Pennington, 1977), Ravenglass (Lloyd et al., 2013), Hallsenna Moor (Walker, 2004) and St Bees (Coope and Joachim, 1980) and ${ }^{10} \mathrm{Be}$ TCN dating from Wasdale (McCarroll et al., 2010) are also useful and provide a timeframe for Lake District deglaciation to the west. Finally, and perhaps most importantly, accurate dating of Shap Fell deglaciation is key to the BIS as it retreated northwards from Shap Fell through the Vale of Eden (Clark et al., 2012). This in turn determines the timing of retreat into the Solway Lowlands (Livingstone et al., 2012) and provides context for the development of an independent ice centre in the Galloway Hills (Ballantyne et al., 2013).

\subsection{Study site}

Shap Fell exhibits numerous north-south oriented drumlins (Clark et al., 2004), formed due to deformation of the basal till layer (Delaney, 2003) and representative of rapid ice flow (Alley $e t$ 
al., 1986), as well as abundant meltwater channels (Arthurton \& Wadge, 1981). Although glacial deposits indicate that ice flow alternated during periods of internal ice sheet reorganisation (Livingstone et al., 2012), the existence of oriented drumlin fields suggests the presence of an ice stream retreating northwards (Livingstone et al., 2008).

A total of 32 samples were obtained from previously unmapped hummocks and drumlins, close to the erratic limit as identified by Clark et al., (2004). These erratics are $\sim 10 \mathrm{~km}$ from the bedrock source and are sufficiently large (1-3m in length) to render post-glacial fluvial transport unlikely. The restricted distribution of these erratics could indicate post-depositional disturbance. However, any disturbance would be unlikely to affect rock hardness, unless significant rock breakup occurred. After excluding one outlier (CR-1), the R value consistency of these samples (37.6 \pm 1.1 , average and mean absolute deviation) indicates that disturbance is not an important factor.

These erratics could have been deposited due to the breakup of an ice dammed lake. However, Clark et al., (2004) report no major ice dammed lakes in the Vale of Eden, in contrast to initial research (Jowett \& Charlesworth, 1929) although early assessments are not verified by glacial deposits (Evans et al., 2005). The only major glacial lake in the area was proglacial, and developed to the north before Scottish ice readvance at $16.8 \mathrm{ka}$ (Livingstone et al., 2010a). The minimum extent of this lake and ice front positions before $16.8 \mathrm{ka}$ are shown in Figure 4 . While this was sufficient to flood the Solway Lowlands $\left(<1350 \mathrm{~km}^{2}\right)$, a floodwater origin for the CR erratics is unlikely, as they are located over $\sim 50 \mathrm{~km}$ upslope. Flooding was more likely to the north and west as glacial retreat of the Scottish ice front could trigger rapid meltwater drainage. Therefore, we conclude these erratics are representative of glacial retreat.

\subsection{Deglaciation}

Based on SHED, Shap Fell underwent deglaciation at $16.5 \pm 0.5$ ka (Figure 5A; Table 4; uncertainty $=$ mean absolute deviation). Modelling of BIS retreat indicates that Shap Fell underwent deglaciation between 17-18 ka (Clark et al., 2012), after $16 \mathrm{ka}$ (Livingstone et al., 2012), at $16 \mathrm{ka}$ (Hubbard et al., 2009) and after $15.5 \mathrm{ka}$ (Evans et al., 2009). The result generated by SHED is in direct agreement with the youngest TCN date from Wilson et al., (2013c) of 16.5 $\pm 1.0 \mathrm{ka}$. If the OSL dates from Telfer et al., (2009) are accepted, this result suggests that deglaciation to the south of the coastal and upland regions occurred by $19.3 \pm 2.6$ and $16.5 \pm 1.7$ ka respectively although the level of uncertainty for these samples makes direct comparison with SHED ages difficult. The ${ }^{14} \mathrm{C}$ age of $17.8 \pm 0.9 \mathrm{ka}$ from Wray Bay (Coope and Pennington, 1977) indicates that lowland deglaciation in the Lake District predated BIS retreat from Shap Fell, although ${ }^{14} \mathrm{C}$ dates from coastal sites (Coope and Joachim, 1980; Walker, 2004; Lloyd et al., 2013) of 14.7-16.5 ka indicate that final deglaciation of the western Lake District may have postdated Shap Fell retreat due to the readvance of marine ice during the Killard Point Stadial (McCabe et al., 2007b). The close correlation of two datasets (SHED, Wilson et al., 2013c) 
which are in agreement with the timeframe for deglaciation provided by modelling, is sufficiently strong to narrow the possible age range of deglaciation at Shap Fell to $16.5 \pm 0.5 \mathrm{ka}$ (Figure 5B).

For granitic lithologies, individual calibrated SHED ages and uncertainties (mean uncertainty = $1.5 \mathrm{ka}$ ) are comparable to the $1.1 \mathrm{ka}$ mean uncertainty from TCND (Wilson et al., 2013c). Moreover, our SHED ages in aggregate provide the strongest estimate for deglaciation simply due to the number of samples $(n=31)$, which highlights the value of low-cost high-sample volume dating.

Despite the $\mathrm{R}$ value consistency of these erratics, sampling of a sufficiently large number of surfaces (>20) is still necessary, as anomalous results (e.g. CR1) can occur. SHED of Shap granite is of particular value as this lithology is an important marker erratic (Evans et al., 2005) given its restricted source area, but widespread local and regional distribution. It is commonly found in the Vale of York (Letzer, 1978) and indicates that ice from Scotland and the Lake District breached the Pennines through the Stainmore Gap (Catt, 2007). Therefore, SHED could be applied to these erratics to constrain the timing of Yorkshire deglaciation and indicate the extent to which North Sea ice shelves extended inland (Davies et al., 2009; Clark et al., 2012) and delayed terrestrial deglaciation, or if they were confined to the periphery of the landmass (Everest et al., 2005).

\section{Conclusions}

This study has established SHED as a viable and cost efficient technique for dating of glacial landforms in the UK. SHED works effectively for granite surfaces and may be applicable beyond $20 \mathrm{ka}$ although further sampling of LLS and Holocene surfaces is recommended. Fieldwork is time consuming, as many samples are required to generate statistically significant results. However, the cost of TCND and the potential for significant errors means that the choice of sampling site is critical (Ballantyne, 2010). This is less important for SHED as multi-sample studies permit straightforward identification of anomalous results, while data can be quickly compiled and analysed. Importantly, it is capable of providing direct ages for landforms and is applicable to many glacial environments, and thus has clear advantages over other techniques which provide indirect or minimum ages $\left({ }^{14} \mathrm{C}\right.$, OSL). This study should provide the foundations for and encourage future applications of SHED.

However, accurate SHED is completely dependent on the correct calculation of calibration curves as minor errors can significantly alter the calculated exposure age. Previous studies have used a limited number of calibration points but given the potential for geological uncertainty, relying on sparse and isolated control points and assuming a linear relationship between them is not recommended and sampling of multiple dated surfaces is necessary. In this study, we show that this strategy is effective, as a robust granite calibration curve has been applied in a region of 
similar climate and generates results that conform to our understanding of regional deglaciation. The retreat of the BIS from Shap Fell at $16.5 \pm 0.5 \mathrm{ka}$ has now been dated using both TCND and SHED, and fits well with a regional pattern of deglaciation established using OSL and ${ }^{14} \mathrm{C}$ dating. This study has shown that SHED can provide independent verification of existing results. However, of greater value will be its application to poorly dated regions where it may provide a cost efficient and reliable first estimate of deglaciation.

\section{Acknowledgements}

We would like to thank C. Ballantyne, T. Bradwell, J. Everest, D. Small and P. Wilson for providing sample photographs which were essential when conducting fieldwork. D. Fabel also kindly provided unpublished calibration data for the LL LPR which permitted exposure age recalibration. We would also like to thank D. Tomkins whose assistance during fieldwork was essential to this research. This study was partially funded by the University of Manchester Zochonis Travel Award 2013/2014 and an Undergraduate Dissertation Bursary provided by the Manchester Geographical Society. Hughes and Dortch would like to thank the University of Manchester Research Stimulation Fund.

\section{References}

Alley, R.B., Blankenship, D.D., Bentley, C.R., Rooney, S.T., 1986. Deformation of till beneath ice stream B, West Antarctica. Nature 322, 57-59. doi:10.1038/322057a0

Applegate, P.J., Urban, N.M., Keller, K., Lowell, T. V., Laabs, B.J.C., Kelly, M. A., Alley, R.B., 2012.

Improved moraine age interpretations through explicit matching of geomorphic process models to cosmogenic nuclide measurements from single landforms. Quat. Res. 77, 293-304.

doi:10.1016/j.yqres.2011.12.002

Arthurton, R.S., Wadge, J.A., 1981. Geology of the country around Penrith. Mem. Geol. Surv. Gt. Britian.

Aydin, A., 2015. The ISRM Suggested Methods for Rock Characterization, Testing and Monitoring: 20072014 2007-2014. doi:10.1007/978-3-319-07713-0

Aydin, A., Basu, A., 2005. The Schmidt hammer in rock material characterization. Eng. Geol. 81, 1-14. doi:10.1016/j.enggeo.2005.06.006

Balco, G., 2011. Contributions and unrealized potential contributions of cosmogenic-nuclide exposure dating to glacier chronology, 1990-2010. Quat. Sci. Rev. 30, 3-27. doi:10.1016/j.quascirev.2010.11.003

Balco, G., Rovey, C.W., 2008. An isochron method for cosmogenic-nuclide dating of buried soils and sediments. Am. J. Sci. 308, 1083-1114. doi:10.2475/10.2008.02

Balco, G., Stone, J.O., Lifton, N. A., Dunai, T.J., 2008. A complete and easily accessible means of calculating surface exposure ages or erosion rates from 10Be and 26Al measurements. Quat. Geochronol. 3, 174-195. doi:10.1016/j.quageo.2007.12.001 
Ballantyne, C.K., 2010. Extent and deglacial chronology of the last British-Irish Ice Sheet: Implications of exposure dating using cosmogenic isotopes. J. Quat. Sci. 25, 515-534. doi:10.1002/jqs.1310

Ballantyne, C.K., 2007. The Loch Lomond Readvance on north Arran, Scotland: Glacier reconstruction and palaeoclimatic implications. J. Quat. Sci. 22, 343-359. doi:10.1002/jqs.1059

Ballantyne, C.K., 2002. The Loch Lomond Stadial on the Isle of Mull, Scotland glacial reconstruction and palaeoclimatic implications. J. Quat. Sci. 17, 759-771. doi:10.1002/jqs.729

Ballantyne, C.K., 1989. The Loch Lomond Readvance on the Isle of Skye, Scotland: glacier reconstruction and palaeoclimatic implications. J. Quat. Sci. 4, 95-108.

Ballantyne, C.K., 1983. Precipitation gradients in Wester Ross, North-West Scotland,. Weather 38, 95108.

Ballantyne, C.K., Black, N.M., Finlay, D.P., 1990. Use of the Schmidt test hammer to detect enhanced boulder weathering under late-lying snowpatches. Earth Surf. Process. Landforms 15, 471-474.

Ballantyne, C.K., Hall, A.M., 2008. The altitude of the last ice sheet in Caithness and east Sutherland, northern Scotland. Scottish J. Geol. 44, 169-181. doi:10.1144/sjg44020169

Ballantyne, C.K., Hall, A.M., Phillips, W., Binnie, S., Kubik, P.W., 2007. Age and significance of former lowaltitude corrie glaciers on Hoy, Orkney Islands. Scottish J. Geol. 43, 107-114. doi:10.1144/sjg43020107

Ballantyne, C.K., McCarroll, D., Stone, J.O., 2006. Vertical dimensions and age of the Wicklow Mountains ice dome, Eastern Ireland, and implications for the extent of the last Irish Ice Sheet. Quat. Sci. Rev. 25, 2048-2058. doi:10.1016/j.quascirev.2006.01.026

Ballantyne, C.K., Rinterknecht, V., Gheorghiu, D.M., 2013. Deglaciation chronology of the Galloway Hills Ice Centre, southwest Scotland. J. Quat. Sci. 28, 412-420. doi:10.1002/jqs.2635

Ballantyne, C.K., Sandeman, G.F., Stone, J.O., Wilson, P., 2014. Rock-slope failure following Late Pleistocene deglaciation on tectonically stable mountainous terrain. Quat. Sci. Rev. 86, 144-157. doi:10.1016/j.quascirev.2013.12.021

Ballantyne, C.K., Schnabel, C., Xu, S., 2009a. Readvance of the last British-Irish Ice Sheet during Greenland Interstade 1 (GI-1): the Wester Ross Readvance, NW Scotland. Quat. Sci. Rev. 28, 783-789. doi:10.1016/j.quascirev.2009.01.011

Ballantyne, C.K., Stone, J.O., 2012. Did large ice caps persist on low ground in north-west Scotland during the Lateglacial Interstade? J. Quat. Sci. 27, 297-306.

Ballantyne, C.K., Stone, J.O., Fifield, L.K., 2009b. Glaciation and deglaciation of the SW Lake District, England: implications of cosmogenic $36 \mathrm{Cl}$ exposure dating. Proc. Geol. Assoc. 120, 139-144. doi:10.1016/j.pgeola.2009.08.003 
Ballantyne, C.K., Stone, J.O., McCarroll, D., 2008. Dimensions and chronology of the last ice sheet in Western Ireland. Quat. Sci. Rev. 27, 185-200. doi:10.1016/j.quascirev.2007.10.019

Blaauw, M., Bakker, R., Christen, J.A., Hall, V. A, Plicht, J. Van Der, 2007. A Bayesian framework for gae modelin of radiocarbon-dates peat deposits: case studies from the Netherlands. Radiocarbon 49, 357367.

Bowen, D., 1986. Correlation of Quaternary glaciations in England, Ireland, Scotland and Wales. Quat. Sci. Rev. 5, 299-340. doi:10.1016/S0277-3791(86)80024-5

Bowen, D.Q., Phillips, F.M., McCabe, A.M., Knutz, P.C., Sykes, G. A., 2002. New data for the Last Glacial Maximum in Great Britain and Ireland. Quat. Sci. Rev. 21, 89-101. doi:10.1016/S0277-3791(01)00102-0

Bradwell, T., Stoker, M.S., Golledge, N.R., Wilson, C.K., Merritt, J.W., Long, D., Everest, J.D., Hestvik, O.B., Stevenson, A.G., Hubbard, A.L., Finlayson, A.G., Mathers, H.E., 2008. The northern sector of the last British Ice Sheet: Maximum extent and demise. Earth-Science Rev. 88, 207-226.

doi:10.1016/j.earscirev.2008.01.008

Briner, J.P., 2011. Dating glacial landforms, in: Singh, V.P., Singh, P., Haritashya, U.K. (Eds.), Encyclopedia of Snow, Ice and Glaciers. Springer Science, pp. 175-186. doi:10.1007/978-90-481-2642-2

Briner, J.P., Kaufman, D.S., Manley, W.F., Finkel, R.C., Caffee, M.W., 2005. Cosmogenic exposure dating of late Pleistocene moraine stabilization in Alaska. Bull. Geol. Soc. Am. 117, 1108-1120.

doi:10.1130/B25649.1

Brook, M.S., Kirkbride, M.P., Brock, B.W., 2004. Rock strength and development of glacial valley morphology in the Scottish Highlands and northwest Iceland. Geogr. Ann. Ser. A Phys. Geogr. 86, 225234. doi:10.1111/j.0435-3676.2004.00227.x

Brooks, S., Axford, Y., Heiri, O., Langdon, P., Larocque-Tobler, I., 2012. Chironomids can be reliable proxies for Holocene temperatures. A comment on Velle et al., 2010. doi:10.1177/0959683612449757

Brooks, S., Birks, H., 2000. Chironomid-inferred late-glacial air temperatures at Whitrig Bog, southeast Scotland 15, 759-764. doi:10.1002/1099-1417(200012)15:8<759::AID-JQS590>3.0.CO;2-V

Brunsdon, C., McClatchey, J., Unwin, D.J., 2001. Spatial variations in the average rainfall-altitude relationship in Great Britain: An approach using geographically weighted regression. Int. J. Climatol. 21, 455-466. doi:10.1002/joc.614

Bursik, M., 1991. Relative dating of moraines based on landform degradation, Lee Vining Canyon, California. Quat. Res. 35, 451-455. doi:10.1016/0033-5894(91)90057-C

Catt, J., 2007. The Pleistocene glaciations of eastern Yorkshire: a review 56, 177-207. doi:10.1144/pygs.56.3.177 
Chiverrell, R.C., Thomas, G.S.P., 2010. Extent and timing of the Last Glacial Maximum (LGM) in Britain and Ireland: A review. J. Quat. Sci. 25, 535-549. doi:10.1002/jqs.1404

Clark, C.D., Evans, D.J., Khatwa, A., Bradwell, T., Jordan, C.J., Marsh, S., Mitchell, W.A., Bateman, M.D., 2004. Map and GIS database of glacial landforms and features related to the last British Ice Sheet.

Boreas 33, 359-375.

Clark, C.D., Hughes, A.L.C., Greenwood, S.L., Jordan, C., Sejrup, H.P., 2012. Pattern and timing of retreat of the last British-Irish Ice Sheet. Quat. Sci. Rev. 44, 112-146. doi:10.1016/j.quascirev.2010.07.019

Cockburn, H. A. P., Summerfield, M. A., 2004. Geomorphological applications of cosmogenic isotope analysis. Prog. Phys. Geogr. 28, 1-42. doi:10.1191/0309133304pp395oa

Colman, S.M., 1981. Rock-weathering rates as functions of time. Quat. Res. 15, 250-264.

doi:10.1016/0033-5894(81)90029-6

Coope, G.R., Joachim, M.J., 1980. Lateglacial environmental changes interpreted from fossil coleoptera from St. Bees, Cumbria, NW England, in: Lowe, J.J., Gray, J., Robinson, J. (Eds.), Studies in the Lateglacial of North-West Europe. Pergamon Journals Ltd., Oxford, pp. 55-68.

Coope, G.R., Pennington, W., 1977. The Windermere Interstadial of the Late Devensian. Philos. Trans. R. Soc. London B 280, 337-340.

Croll, J., 1875. Climate and Time in Their Geological Relations. A theory of secular changes of the earth's climate. New York.

Dahl, S.O., Nesje, A., Lie, Ø., Fjordheim, K., Matthews, J. a., 2002. Timing, equilibrium-line altitudes and climatic implications of two early-Holocene glacier readvances during the Erdalen Event at Jostedalsbreen, western Norway. The Holocene 12, 17-25. doi:10.1191/0959683602hl516rp

Darvill, C.M., 2013. Cosmogenic nuclide analysis. Geomophological Tech. 10, 1-25.

Davies, B.J., Bridgland, D.R., Roberts, D.H., Cofaigh, C.Ó., Pawley, S.M., Candy, I., Demarchi, B., Penkman, K.E.H., Austin, W.E.N., 2009. The age and stratigraphic context of the Easington Raised Beach, County Durham, UK. Proc. Geol. Assoc. 120, 183-198. doi:10.1016/j.pgeola.2009.04.001

Day, M.J., Goudie, A.S., 1977. Field assessment of rock hardness using the Schmidt test hammer. BGR Tech. Bull. 18, 19-29.

Deere, D.U., Miller, R.P., 1966. Engineering classifications and index properties of intact rock, Technical Report AFWL-TR 65-115.

Dehnert, A., Schlüchter, C., 2008. Sediment burial dating using terrestrial cosmogenic nuclides. Eiszeitalter und Gegenwart - Quat. Sci. J. 57, 210-225. doi:http://dx.doi.org/10.3285/eg.57.1-2.8

Delaney, C., 2003. The Last Glacial Stage (the Devensian) in Northwest England 3. 
Demirdag, S., Yavuz, H., Altindag, R., 2009. The effect of sample size on Schmidt rebound hardness value of rocks. Int. J. Rock Mech. Min. Sci. 46, 725-730. doi:10.1016/j.ijrmms.2008.09.004

Dortch, J.M., Owen, L. A., Caffee, M.W., 2013. Timing and climatic drivers for glaciation across semi-arid western Himalayan-Tibetan orogen. Quat. Sci. Rev. 78, 188-208. doi:10.1016/j.quascirev.2013.07.025

Dortch, J.M., Owen, L. A., Caffee, M.W., Brease, P., 2009a. Late Quaternary glaciation and equilibrium line altitude variations of the McKinley River region, central Alaska Range. Boreas 39, 233-246. doi:10.1111/j.1502-3885.2009.00121.x

Dortch, J.M., Owen, L. A., Haneberg, W.C., Caffee, M.W., Dietsch, C., Kamp, U., 2009b. Nature and timing of large landslides in the Himalaya and Transhimalaya of northern India. Quat. Sci. Rev. 28, 1037-1054. doi:10.1016/j.quascirev.2008.05.002

Dortch, J.M., Owen, L.A., Caffee, M.W., 2010a. Quaternary glaciation in the Nubra and Shyok valley confluence, northernmost Ladakh, India. Quat. Res. 74, 132-144.

Dortch, J.M., Owen, L.A., Caffee, M.W., Li, D., Lowell, T. V., 2010b. Beryllium-10 surface exposure dating of glacial successions in the Central Alaska Range. J. Quat. Sci. 25, 1259-1269.

Dunne, J., Elmore, D., Muzikar, P., 1999. Scaling factors for the rates of production of cosmogenic nuclides for geometric shielding and attenuation at depth on sloped surfaces. Geomorphology 27, 3-11. doi:10.1016/S0169-555X(98)00086-5

Engel, Z., 2007. Measurement and age assignment of intact rock strength in the Krkonoše Mountains, Czech Republic. Zeitschrift für Geomorphol. 51, 69-80.

Engineering geology field manual: field index tests, 1998. . U.S. Bureau of Reclamation.

Ericson, K., 2004. Geomorphological surfaces of different age and origin in granite landscapes: An evaluation of the Schmidt hammer test. Earth Surf. Process. Landforms 29, 495-509.

doi:10.1002/esp.1048

Evans, D.J. A, Livingstone, S.J., Vieli, A., Ó Cofaigh, C., 2009. The palaeoglaciology of the central sector of the British and Irish Ice Sheet: reconciling glacial geomorphology and preliminary ice sheet modelling. Quat. Sci. Rev. 28, 739-757. doi:10.1016/j.quascirev.2008.05.011

Evans, D.J. A., Archer, S., Wilson, D.J.H., 1999. A comparison of the lichenometric and Schmidt hammer dating techniques based on data from the proglacial areas of some Icelandic glaciers. Quat. Sci. Rev. 18, 13-41. doi:10.1016/S0277-3791(98)00098-5

Evans, D.J.A., Clark, C., Mitchell, W.A., 2005. The last British Ice Sheet: A review of the evidence utilised in the compilation of the Glacial Map of Britain. Earth Sci. Rev. 70, 253-312.

Everest, J., Bradwell, T., Golledge, N., 2005. Subglacial landforms of the tweed palaeo-ice stream. Scottish Geogr. J. 121, 163-173. doi:10.1080/00369220518737229 
Everest, J., Kubik, P., 2006. The deglaciation of eastern Scotland: Cosmogenic 10Be evidence for a Lateglacial stillstand. J. Quat. Sci. 21, 95-104. doi:10.1002/jqs.961

Everest, J.D., Bradwell, T., Fogwill, C.J., Kubik, P.W., 2006. Cosmogenic 10BE age constraints for the Wester Ross Readvance moraine: Insights into British Ice-Sheet behaviour. Geogr. Ann. Ser. A Phys. Geogr. 88, 9-17. doi:10.1111/j.0435-3676.2006.00279.x

Everest, J.D., Bradwell, T., Stoker, M., Dewey, S., 2013. New age constraints for the maximum extent of the last British-Irish Ice Sheet (NW sector). J. Quat. Sci. 28, 2-7. doi:10.1002/jqs.2603

Fabel, D., Ballantyne, C.K., Xu, S., 2012. Trimlines, blockfields, mountain-top erratics and the vertical dimensions of the last British-Irish Ice Sheet in NW Scotland. Quat. Sci. Rev. 55, 91-102.

doi:10.1016/j.quascirev.2012.09.002

Ffoulkes, C., Harrison, S., 2014. Evaluating the Schmidt Hammer as a method for distinguishing the relative age of late Holocene moraines: Svellnosbreen, Jotunheimen, Norway. Geogr. Ann. Ser. A, Phys. Geogr. 96, 393-402.

Fowell, R.J., McFeat Smith, I., 1976. Factors influencing the cutting performance of a selective tunnelling machine. Tunn. proc int symp IMM.

Geikie, J., 1984. The Great Ice Age and Its Relation to the Antiquity of Man. Edward Stanford, London.

Glasser, N.F., Hughes, P.D., Fenton, C., Schnabel, C., Rother, H., 2012. 10Be and 26Al exposure-age dating of bedrock surfaces on the Aran ridge, Wales: Evidence for a thick Welsh Ice Cap at the Last Glacial Maximum. J. Quat. Sci. 27, 97-104. doi:10.1002/jqs.1519

Goktan, R., Ayday, C., 1993. A suggested improvement to the Schmidt rebound hardness ISRM suggested method with particular reference to rock machineability. Int. J. Rock Mech. Min. Sci. 30, 321322.

Goktan, R.M., Gunes, N., 2005. A comparative study of Schmidt hammer testing procedures with reference to rock cutting machine performance prediction. Int. J. Rock Mech. Min. Sci. 42, 466-472. doi:10.1016/j.ijrmms.2004.12.002

Golledge, N., Fabel, D., Everest, J., Freeman, S., Binn, 2007. First cosmogenic 10Be age constrain on the timing of Younger Dryas glaciaton and ice cap thickness, western Scottish Highlands. J. Quat. Sci. 22, 785-791. doi:10.1002/jqs

Golledge, N.R., 2010. Glaciation of Scotland during the Younger Dryas stadial: A review. J. Quat. Sci. 25, 550-566. doi:10.1002/jqs.1319

Gosse, J.C., Phillips, F.M., 2001. Terrestrial in situ cosmogenic nuclides:theory and application. Quat. Sci. Rev. 20, 1475-1560. 
Goudie, A., Mignon, P., Allison, R., Rosser, N., 2002. Sandstone geomorphology of the Al Quwayra area of south Jordan. Zeitschrift für Geomorphol. 46, 365-390.

Goudie, A.S., 2006. The Schmidt Hammer in geomorphological research. Prog. Phys. Geogr. 30, 703-718. doi:10.1016/B978-0-12-374739-6.00398-5

Hall, K., 1993. Enhanced bedrock weathering in association with late-lying snowpatches: Evidence from Livingston Island, Antarctica. Earth Surf. Process. Landforms 18, 121-129.

Hallet, B., Putkonen, J., 1994. Surface dating of dynamic landforms: Young boulders on aging moraines. Science 265, 937-940. doi:10.1126/science.265.5174.937

Harrison, S., Rowan, A. V., Glasser, N.F., Knight, J., Plummer, M. A., Mills, S.C., 2014. Little Ice Age glaciers in Britain: Glacier-climate modelling in the Cairngorm Mountains. The Holocene 24, 135-140. doi:10.1177/0959683613516170

Heyman, J., Stroeven, A.P., Harbor, J.M., Caffee, M.W., 2011. Too young or too old: Evaluating cosmogenic exposure dating based on an analysis of compiled boulder exposure ages. Earth Planet. Sci. Lett. 302, 71-80. doi:10.1016/j.epsl.2010.11.040

Holmes, R., 1997. Reflections on the Ice Age in Scotland: An Update on Quaternary Studies, in: Gordon, J.E. (Ed.), . The Scottish Association of Geography Teachers and Scottish Natural Heritage, Glasgow, pp. 72-94.

Hubbard, A., Bradwell, T., Golledge, N., Hall, A., Patton, H., Sugden, D., Cooper, R., Stoker, M., 2009. Dynamic cycles, ice streams and their impact on the extent, chronology and deglaciation of the BritishIrish ice sheet. Quat. Sci. Rev. 28, 758-776. doi:10.1016/j.quascirev.2008.12.026

Hucka, V., 1965. A rapid method of determining the strength of rocks in situ. Int. J. Rock Mech. Min. Sci. 2, 127-134. doi:10.1016/0148-9062(65)90009-4

Hughes, A.L.C., Greenwood, S.L., Clark, C.D., 2011. Dating constraints on the last British-Irish Ice Sheet: a map and database. J. Maps 7, 156-184. doi:10.4113/jom.2011.1145

Hughes, P.D., Braithwaite, R.J., Fenton, C.R., Schnabel, C., 2012. Two Younger Dryas glacier phases in the English Lake District: geomorphological evidence and preliminary 10Be exposure ages. North West Geogr. 12, 10-19.

Hughes, P.D., Glasser, N.F., Fink, D., 2016. Rapid thinning of the Welsh Ice Cap at 20-19 ka based on ${ }^{10} \mathrm{Be}$ ages. Quaternary Research. DOI: 10.1016/j.yqres.2015.11.003

Internation Society for Rock Mechanics, 1978. Suggested Methods for Determining Hardness and Abrasiveness of Rocks. Int. J. Rock Mech. Min. Sci. 15, 89-97.

Ivy-Ochs, S., Kerschner, H., Reuther, A., Preusser, F., Heine, K., Maisch, M., Kubik, P., Schlüchter, C., 2008. Chronology of the last glacial cycle in the European Alps. J. Quat. Sci. 23, 559-575. doi:10.1002/jqs 
Jowett, A., Charlesworth, J., 1929. The glacial geology of the Derbyshire Dome and western slopes of the southern Pennines. J. Geol. Soc. London 85, 307-334.

Katz, O., Reches, Z., Roegiers, J.C., 2000. Evaluation of mechanical rock properties using a Schmidt Hammer. Int. J. Rock Mech. Min. Sci. 37, 723-728. doi:10.1016/S1365-1609(00)00004-6

Kazi, A., Al-Mansour, R., 1980. Empirical relationship between Los Angeles abrasion and Schmidt hammer strength tests with application to aggregates around Jeddah. Q. J. Eng. Geol. Hydrogeol. 13, 4552.

Kirkbride, M., Everest, J., Benn, D., Gheorghiu, D., Dawson, A., 2014. Late-Holocene and Younger Dryas glaciers in the northern Cairngorm Mountains, Scotland. The Holocene 24, 141-148.

doi:10.1177/0959683613516171

Kirkbride, M.P., Bell, C.M., 2010. Edge-roundness of boulders of Torridonian Sandstone (northwest Scotland): Applications for relative dating and implications for warm and cold climate weathering rates. Boreas 39, 187-198. doi:10.1111/j.1502-3885.2009.00131.x

Kłapyta, P., 2013. Application of Schmidt hammer relative age dating to Late Pleistocene moraines and rock glaciers in the Western Tatra Mountains, Slovakia. Catena 111, 104-121.

doi:10.1016/j.catena.2013.07.004

Lal, D., 1991. Cosmic ray labeling of erosion surfaces: in situ nuclide production rates and erosion models. Earth Planet. Sci. Lett. 104, 424-439. doi:10.1016/0012-821X(91)90220-C

Letzer, J., 1978. The glacial geomorphology of the region bounded by Shap Fells, Stainmore and the Howgill Fells in East Cumbria. University of London.

Li, Y.K., 2013. Determining topographic shielding from digital elevation models for cosmogenic nuclide analysis: A GIS approach and field validation. J. Mt. Sci. 10, 355-362. doi:10.1007/s11629-013-2564-1

Licciardi, J.M., Pierce, K.L., 2008. Cosmogenic exposure-age chronologies of Pinedale and Bull Lake glaciations in greater Yellowstone and the Teton Range, USA. Quat. Sci. Rev. 27, 814-831.

doi:10.1016/j.quascirev.2007.12.005

Livingstone, S.J., Evans, D.J. a, Ó Cofaigh, C., Davies, B.J., Merritt, J.W., Huddart, D., Mitchell, W. A., Roberts, D.H., Yorke, L., 2012. Glaciodynamics of the central sector of the last British-Irish Ice Sheet in Northern England. Earth-Science Rev. 111, 25-55. doi:10.1016/j.earscirev.2011.12.006

Livingstone, S.J., O'Cofaigh, C., Evans, D.J. A., 2008. Glacial geomorphology of the central sector of the last British-Irish ice sheet. 37-41. doi:10.4113/jom.2008.1032

Livingstone, S.J., O'Cofaigh, C., Evans, D.J.A., Palmer, A., 2010. Glaciolacustrine sedimentation in the Solway Lowlands (Cumbria,UK ): evidence for a major glacial oscillation during Late Devensian deglaciation. Boreas 39, 505-527. 
Lloyd, J.M., Zong, Y., Fish, P., Innes, J.B., 2013. Holocene and Lateglacial relative sea-level change in north-west England: Implications for glacial isostatic adjustment models. J. Quat. Sci. 28, 59-70. doi:10.1002/jqs.2587

Lowe, J.J., Rasmussen, S.O., Björck, S., Hoek, W.Z., Steffensen, J.P., Walker, M.J.C., Yu, Z.C., 2008. Synchronisation of palaeoenvironmental events in the North Atlantic region during the Last Termination: a revised protocol recommended by the INTIMATE group. Quat. Sci. Rev. 27, 6-17. doi:10.1016/j.quascirev.2007.09.016

Mann, M.E., Zhang, Z., Hughes, M.K., Bradley, R.S., Miller, S.K., Rutherford, S., Ni, F., 2008. Proxy-based reconstructions of hemispheric and global surface temperature variations over the past two millennia. Proc. Natl. Acad. Sci. U. S. A. 105, 13252-13257. doi:10.1073/pnas.0805721105

Marrero, S., Phillips, F., Borchers, B., Lifton, N., 2016. Cosmogenic Nuclide Systematics and the CRONUScalc Program. Quat. Geochronol. 31, 1-72. doi:10.1016/j.quageo.2015.09.005

Marshak, S., 2009. Essentials of Geology, 3rd ed. W.W. Norton.

Matsukura, Y., Matsuoka, N., 1996. Effect of rock properties on rates of tafoni growth in coastal environments. Zeitschrift für Geomorphol. 106, 57-72.

Matsukura, Y., Tanaka, Y., 2000. Effect of Rock Hardness and Moisture Content on Tafoni Weathering in the Granite of Mount Doeg-Sung, Korea. Geogr. Ann. Ser. A, Phys. Geogr. 82, 59-67.

doi: $10.2307 / 521442$

Matthews, J. A., 2005. Little Ice Age' glacier variations in Jotunheimen, southern Norway: a study in regionally controlled lichenometric dating of recessional moraines with implications for climate and lichen growth rates 1, 1-19. doi:10.1191/0959683605hl779rp

Matthews, J. A., Dresser, P.Q., 2008. Holocene glacier variation chronology of the Smorstabbtindan massif, Jotunheimen, southern Norway, and the recognition of century- to millennial-scale European Neoglacial Events. The Holocene 18, 181-201. doi:10.1177/0959683607085608

Matthews, J. A., Owen, G., 2010. Schmidt hammer exposure-age dating: Developing linear agecalibration curves using Holocene bedrock surfaces from the Jotunheimen-Jostedalsbreen regions of southern Norway. Boreas 39, 105-115. doi:10.1111/j.1502-3885.2009.00107.x

Matthews, J. A., Owen, G., 2008. Endolithic lichens, rapid biological weathering and schmidt hammer $r$ values on recently exposed rock surfaces: Storbreen glacier foreland, jotunheimen, Norway. Geogr. Ann. Ser. A Phys. Geogr. 90, 287-297. doi:10.1111/j.1468-0459.2008.00346.x

Matthews, J. A., Winkler, S., 2011. Schmidt-hammer exposure-age dating (SHD): Application to early Holocene moraines and a reappraisal of the reliability of terrestrial cosmogenic-nuclide dating (TCND) at Austanbotnbreen, Jotunheimen, Norway. Boreas 40, 256-270. doi:10.1111/j.1502-3885.2010.00178.x 
Matthews, J. A., Shakesby, R., 1984. The status of the "Little Ice Age"in southern Norway: relative-age dating of Neoglacial moraines with Schmidt hammer and lichenometry. Boreas 13, 333-346.

McCabe, A. M., Clark, P.U., Clark, J., 2007. Radiocarbon constraints on the history of the western Irish ice sheet prior to the Last Glacial Maximum. Geology 35, 147-150. doi:10.1130/G23167A.1

McCarroll, D., 1989. Schmidt hammer relative-age evaluation of a possible pre-"Little Ice Age' Neoglacial moraine, Leirbreen, southern Norway. Nor. Geol. Tidsskr. 69, 125-130.

McCarroll, D., 1987. The Schmidt hammer in Geomorphology: five sources of instrument error. Br. Geomorphol. Res. Gr. Tech. Bull. 36, 16-27.

McCarroll, D., Stone, J.O., Ballantyne, C.K., Scourse, J.D., Fifield, L.K., Evans, D.J. A, Hiemstra, J.F., 2010. Exposure-age constraints on the extent, timing and rate of retreat of the last Irish Sea ice stream. Quat. Sci. Rev. 29, 1844-1852. doi:10.1016/j.quascirev.2010.04.002

Mellor, A, Short, J., Kirkby, S.J., 1997. Tafoni in the El Chorro Area, Andalucia, Southern Spain. Earth Surf. Process. Landforms 22, 817-833. doi:10.1002/(SICI)1096-9837(199709)22:9<817::AID-ESP768>3.0.CO;2$\mathrm{T}$

Mignon, P., Placek, A., 2007. Rock control and geomorphology of a rocky sandstone scarp, Middle Sudetes Mountains, SW Poland. Zeitschrift für Geomorphol. 51, 41-55.

Owen, G., Owen, G., Matthews, J. A., Albert, P.G., 2007. Rates of Holocene chemical weathering, "Little Ice Age" glacial erosion, and implications for Schmidt-hammer dating at a glacier-foreland boundary, Fåbergstølsbreen, southern Norway 6, 829-834. doi:10.1177/0959683607081419

Owen, L. A., Dortch, J.M., 2014. Nature and timing of Quaternary glaciation in the Himalayan-Tibetan orogen. Quat. Sci. Rev. 88, 14-54. doi:10.1016/j.quascirev.2013.11.016

Phillips, F.M., 1994. Surface Exposure Dating of Glacial Features in Great Britain Using Cosmogenic Chlorine-36: Preliminary Results. Mineral. Mag. 58A, 722-723. doi:10.1180/minmag.1994.58A.2.113

Phillips, F.M., Argento, D.C., Balco, G., Caffee, M.W., Clem, J., Dunai, T.J., Finkel, R., Goehring, B., Gosse, J.C., Hudson, A.M., Jull, A. J.T., Kelly, M. A., Kurz, M., Lal, D., Lifton, N., Marrero, S.M., Nishiizumi, K., Reedy, R.C., Schaefer, J., Stone, J.O.H., Swanson, T., Zreda, M.G., 2015. The CRONUS-Earth Project: A Synthesis. Quat. Geochronol. 31, 119-154. doi:10.1016/j.quageo.2015.09.006

Phillips, W., Hall, A.M., Ballantyne, C.K., Binnie, S.A., Kubik, P.W., Freeman, S.P.H.T., 2008. Extent of the last ice sheet in northern Scotland tested with cosmogenic 10Be exposure ages. J. Quat. Sci. 23, 101107. doi:10.1002/jqs

Poole, R., Farmer, I., 1980. Consistency and repeatability of Schmidt hammer rebound data during field testing. Int. J. Rock Mech. Min. Sci. 17, 167-171. 
Pope, G., 1995. Newly Discovered Submicron-Scale Weathering in Quartz: Geographical Implications. Prof. Geogr. 47, 375-387.

Putkonen, J., Swanson, T., 2003. Accuracy of cosmogenic ages for moraines. Quat. Res. 59, 255-261. doi:10.1016/S0033-5894(03)00006-1

Rode, M., Kellerer-Pirklbauer, A., 2012. Schmidt-hammer exposure-age dating (SHD) of rock glaciers in the Schoderkogel-Eisenhut area, Schladminger Tauern Range, Austria. The Holocene 22, 761-771. doi:10.1177/0959683611430410

Rose, J., 2009. Early and Middle Pleistocene landscapes of eastern England. Proc. Geol. Assoc. 120, 3-33. doi:10.1016/j.pgeola.2009.05.003

Rose, J., Moorlock, B.S.P., Hamblin, R.J.O., 2001. Pre-Anglian fluvial and coastal deposits in Eastern England: Lithostratigraphy and palaeoenvironments. Quat. Int. 79, 5-22. doi:10.1016/S10406182(00)00119-1

Sánchez, J.S., Fernández Mosquera, D., Vidal Romaní, J., 2009. Assessing the age-weathering correspondence of comsogenic $21 \mathrm{Ne}$ dated Pleistocene surfaces by the Schmidt Hammer. Earth Surf. Process. Landforms 34, 1121-1125. doi:10.1002/esp

Schimmelpfennig, I., Benedetti, L., Finkel, R., Pik, R., Blard, P.H., Bourlès, D., Burnard, P., Williams, A., 2009. Sources of in-situ $36 \mathrm{Cl}$ in basaltic rocks. Implications for calibration of production rates. Quat. Geochronol. 4, 441-461. doi:10.1016/j.quageo.2009.06.003

Schwamborn, G., Schirrmeister, L., Frütsch, F., Diekmann, B., 2012. Quartz weathering in freeze-thaw cycles: Experiment and application to the el'gygytgyn crater lake record for tracing Siberian permafrost history. Geogr. Ann. Ser. A Phys. Geogr. 94, 481-499. doi:10.1111/j.1468-0459.2012.00472.x

Scourse, J.D., Haapaniemi, A.I., Colmenero-Hidalgo, E., Peck, V.L., Hall, I.R., Austin, W.E.N., Knutz, P.C., Zahn, R., 2009. Growth, dynamics and deglaciation of the last British-Irish ice sheet: the deep-sea icerafted detritus record. Quat. Sci. Rev. 28, 3066-3084. doi:10.1016/j.quascirev.2009.08.009

Sejrup, H.P., Hjelstuen, B.O., Dahlgren, K.I.T., Haflidason, H., Kuijpers, A., Nygård, A., Praeg, D., Stoker, M.S., Vorren, T.O., 2005. Pleistocene glacial history of the NW European continental margin. Mar. Pet. Geol. 22, 1111-1129. doi:10.1016/j.marpetgeo.2004.09.007

Selby, M., 1993. Hillslope materials and processes. Oxford University Press, Oxford.

Selby, M., 1980. A rock-mass strength classifi cation for geomorphic purposes: with tests from Antarctica and New Zealand. Zeitschrift für Geomorphol. N.F 24, 31-51.

Shakesby, R. A., Matthews, J. A., Owen, G., 2006. The Schmidt hammer as a relative-age dating tool and its potential for calibrated-age dating in Holocene glaciated environments. Quat. Sci. Rev. 25, 28462867. doi:10.1016/j.quascirev.2006.07.011 
Shakesby, R. A., Matthews, J. A., Karlén, W., Los, S., 2011. The Schmidt hammer as a Holocene calibrated-age dating technique: Testing the form of the R-value-age relationship and defining the predicted-age errors. doi:10.1177/0959683610391322

Sissons, J.B., 1979. The Loch Lomond Stadial in the British Isles. Nature 280, 199-203. doi:10.1038/280199a0

Sjöberg, R., Broadbent, N., 1991. Measurement and calibration of weathering, using the Schmidt hammer, on wave washed moraines on the upper Norrland Coast, Sweden. Earth Surf. Process. Landforms 16, 57-64. doi:10.1016/0148-9062(91)90609-P

Small, D., Rinterknecht, V., Austin, W., Fabel, D., Miguens-Rodriguez, M., Xu, S., 2012. In situ cosmogenic exposure ages from the Isle of Skye, northwest Scotland: Implications for the timing of deglaciation and readvance from 15 to $11 \mathrm{ka}$. J. Quat. Sci. 27, 150-158. doi:10.1002/jqs.1522

Soiltest, 1976. Operating instructions-concrete test hammer.

Stahl, T., Winkler, S., Quigley, M., Bebbington, M., Duffy, B., Duke, D., 2013. Schmidt hammer exposureage dating (SHD) of late Quaternary fluvial terraces in New Zealand. Earth Surf. Process. Landforms 38, 1838-1850. doi:10.1002/esp.3427

Stone, J.O., 2000. isotope production T , T , 105, 753-759.

Stone, J.O., Ballantyne, C.K., Fifield, L.K., 1998. Exposure dating and validation of periglacial weathering limits, northwest Scotland. Geology 26, 587-590. doi:10.1130/0091-

7613(1998)026<0587:EDAVOP>2.3.CO

Sumner, P., Nel, W., 2002. The effect of rock moisture on Schmidt hammer rebound: Tests on rock samples from Marion Island and South Africa. Earth Surf. Process. Landforms 27, 1137-1142.

doi:10.1002/esp.402

Sumner, P., Nel, W., Holness, S., Boelhouwers, J., 2002. Rock Weathering Characteristics As Relative-Age Indicators for Glacial and Post-Glacial Landforms on Marion Island. South African Geogr. J. 84, 153-157. doi:10.1080/03736245.2002.9713766

Swanson, T.W., Caffee, M.L., 2001. Determination of 36Cl Production Rates Derived from the Well-Dated Deglaciation Surfaces of Whidbey and Fidalgo Islands, Washington. Quat. Res. 56, 366-382.

doi:10.1006/qres.2001.2278

Telfer, M.W., Wilson, P., Lord, T.C., Vincent, P.J., 2009. New constraints on the age of the last ice sheet glaciation in NW England using optically stimulated luminescence dating. J. Quat. Sci. 24, 906-915.

doi:10.1002/jqs

Turkington, A. V., Paradise, T.R., 2005. Sandstone weathering: A century of research and innovation. Geomorphology 67, 229-253. doi:10.1016/j.geomorph.2004.09.028 
Viles, H., Goudie, A., Grab, S., Lalley, J., 2011. The use of the Schmidt Hammer and Equotip for rock hardness assessment in geomorphology and heritage science: A comparative analysis. Earth Surf. Process. Landforms 36, 320-333. doi:10.1002/esp.2040

Vincent, P.J., Wilson, P., Lord, T.C., Schnabel, C., Wilcken, K.M., 2010. Cosmogenic isotope (36Cl) surface exposure dating of the Norber erratics, Yorkshire Dales: Further constraints on the timing of the LGM deglaciation in Britain. Proc. Geol. Assoc. 121, 24-31. doi:10.1016/j.pgeola.2009.12.009

Walker, M.J.C., 2004. A Lateglacial pollen record from Hallsenna Moor, near Seascale, Cumbria, NW England, with evidence for arid conditions during the Loch Lomond (Younger Dryas) Stadial and early Holocene. Proc. Yorksh. Geol. Soc. 55, 33-42.

White, A.F., Brantley, S.L., 2003. The effect of time on the weathering of silicate minerals: Why do weathering rates differ in the laboratory and field? Chem. Geol. 202, 479-506.

doi:10.1016/j.chemgeo.2003.03.001

White, K., Bryant, R., Drake, N., 1998. Techniques for measuring rock weathering: Application to a dated fan segment sequence in southern Tunisia. Earth Surf. Process. Landforms 23, 1031-1043.

doi:10.1002/(SICI)1096-9837(1998110)23:11<1031::AID-ESP919>3.0.CO;2-G

Williams, R.B.G., Robinson, D. A, 1983. The effect of surface texture on the determination of the surface hardness of rock using the Schmidt hammer. Earth Surf. Process. Landforms 8, 289-292.

Wilson, P., Lord, T., Rodés, Á., 2013a. Deglaciation of the eastern Cumbria glaciokarst, northwest England, as determined by cosmogenic nuclide (10Be) surface exposure dating, and the pattern and significance of subsequent environmental changes. Cave Karst Sci. 40, 22-27.

Wilson, P., Schnabel, C., Wilcken, K.M., Vincent, P.J., 2013b. Surface exposure dating (36Cl and $10 \mathrm{Be})$ of post-Last Glacial Maximum valley moraines, Lake District, northwest England: Some issues and implications. J. Quat. Sci. 28, 379-390. doi:10.1002/jqs.2628

Winkler, S., 2009. First attempt to combine terrestrial cosmogenic nuclide (10Be) and Schmidt hammer relative-age dating: Strauchon Glacier, Southern Alps, New Zealand. Cent. Eur. J. Geosci. 1, 274-290. doi:10.2478/v10085-009-0026-3

Winkler, S., 2005. The Schmidt hammer as a relative-age dating technique: Potential and limitations of its application on Holocene moraines in Mt Cook National Park, Southern Alps, New Zealand. New Zeal. J. Geol. Geophys. 48, 105-116. doi:10.1080/00288306.2005.9515102

Young, R., Fowell, R.J., 1978. Assessing rock discontinuities. Tunnels \& Tunnelling 45-48. 
Figure 1: Digital elevation model (DEM) of the UK showing the location of TCND ages and SHED sampling sites used in this study. Traditional extent of BIS redrawn from Bowen et al. (1986) and updated extent from Sejrup et al. (2005).

Figure 2: Selected photos of previously dated boulders utilized for Schmidt hammer calibration showing rock removal for cosmogenic analysis (outlined). A) Gneiss boulder in the Orkneys, B) Granite boulder in Coire an Lochan, Cairngorms, C) Sandstone boulder on the Redpoint moraine, Wester Ross , and D) Quartz boulder on Maol Chean Dearg, Torridon

Figure 3: R Value vs. ${ }^{10}$ Be age calibration curves for lithologies presented in this study. A) Granite calibration curve, B) Sandstone calibration curve, C) Quartz calibration curve, D) Gneiss calibration curve, and E) Tuff calibration curve. Regression lines are demarked by solid red lines. Blue and grey dashed lines mark one and two sigma boundaries. Data used is shown by red dots with black error bars and outliers excluded from the calibration are shown by yellow dots with green error bars.

Figure 4: DEM of NW England showing location of SHED, TCND, OSL and 14C samples used to date BIS retreat. Data taken from Coope and Pennington (1977), Coope and Joachim (1980), Walker (2004), Telfer et al. (2009), McCarroll (2010), Wilson et al. (2013c), Lloyd et al. (2013). Erratic source areas, erratic limits and drumlins after Clark et al. (2004) and ice front and Blackhall Wood lake extent from Livingstone et al. (2010).

Figure 5: A) Plot of 32 SHED ages after calibration from R Value to numerical age (black dots with error bars). The mean and absolute mean deviation is shown by red dot and error bars with limits marked by a horizontal grey bar. B) Comparison of TCND (green), OSL (blue) and ${ }^{14} \mathrm{C}$ (black) ages with the SHED mean age (red) and associated error bars for NW England. Green horizontal bar denotes preferred TCND age range from Wilson et al. (2013c). Horizontal grey bar marks the age range of the SHED mean age. Note the overlap between methods and the reduction of uncertainty provided by the SHED method. 


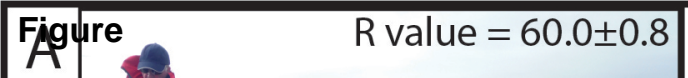

\section{Figure}

$\mathrm{R}$ value $=60.0 \pm 0.8$

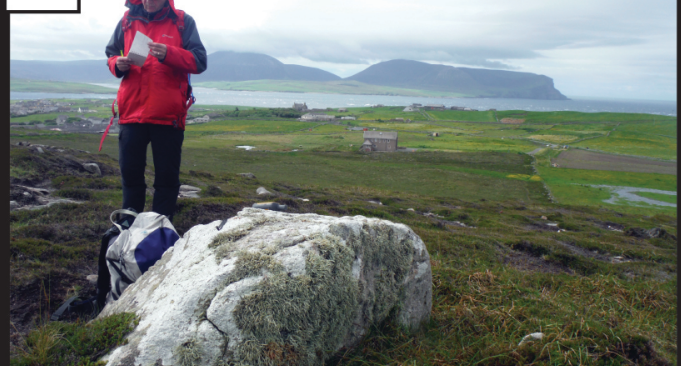

Ork 2, Phillips et al. 2008

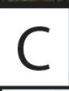
$R$ value $=56.1 \pm 0.6$

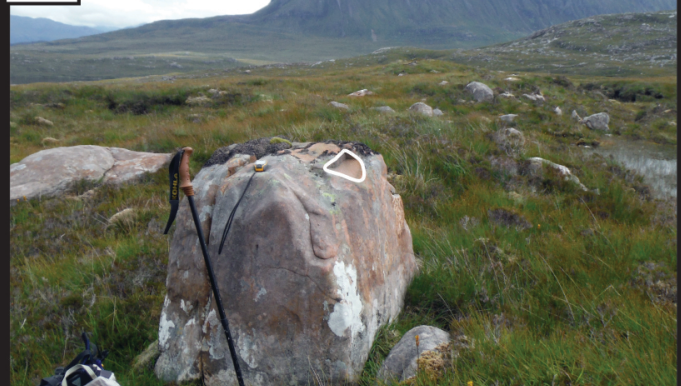

1. RM-01, Ballantyneret al. 2009

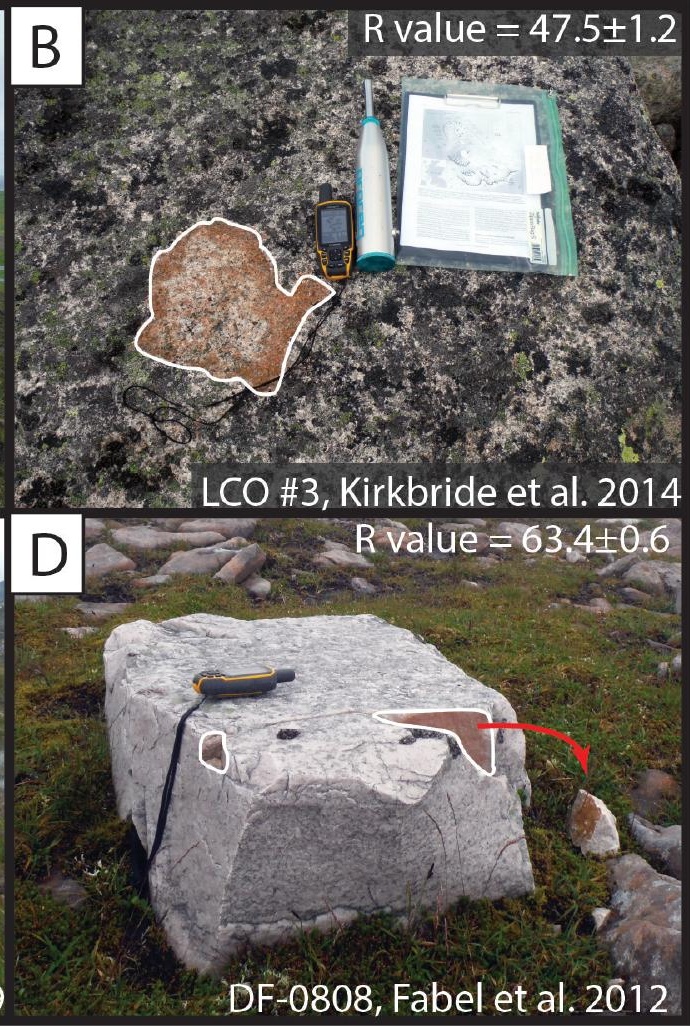

LCO \#3, Kirkbride et al. 2014

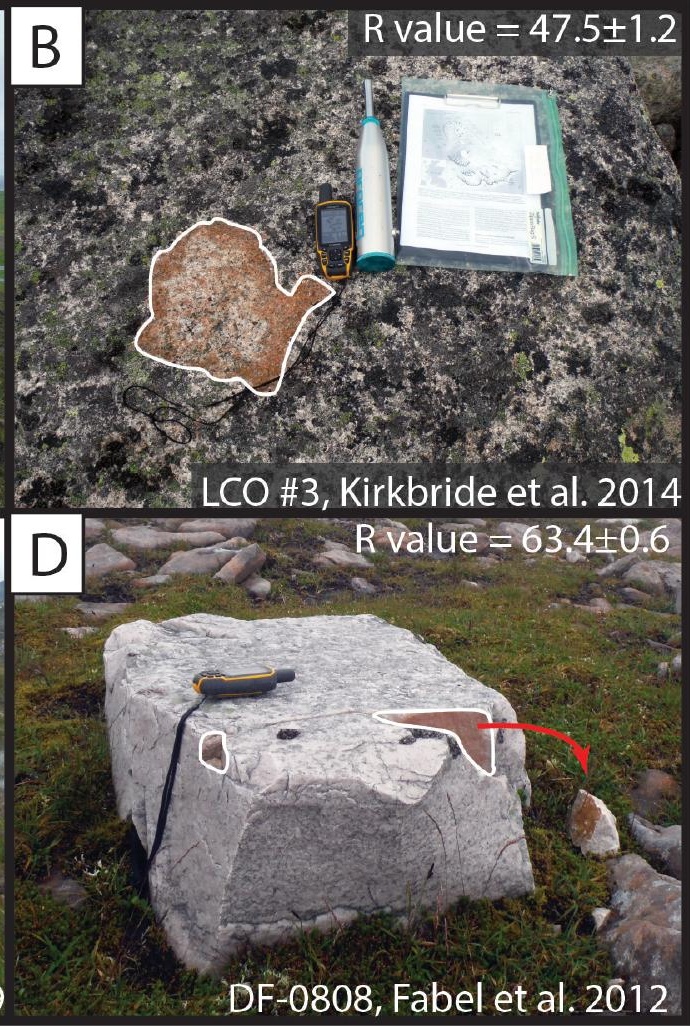

R value

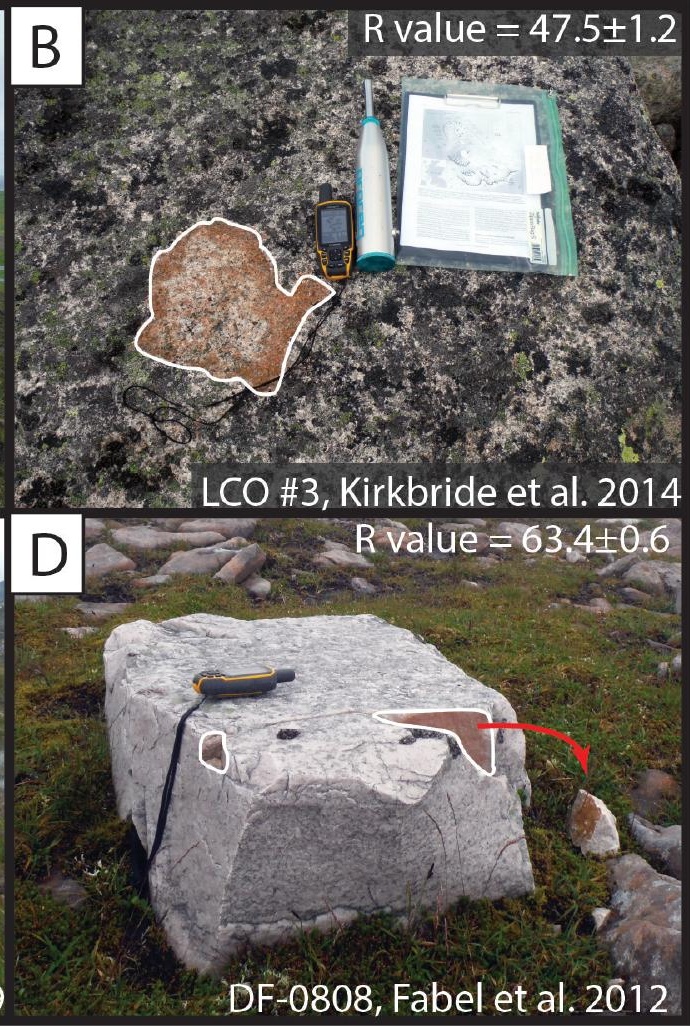

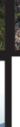
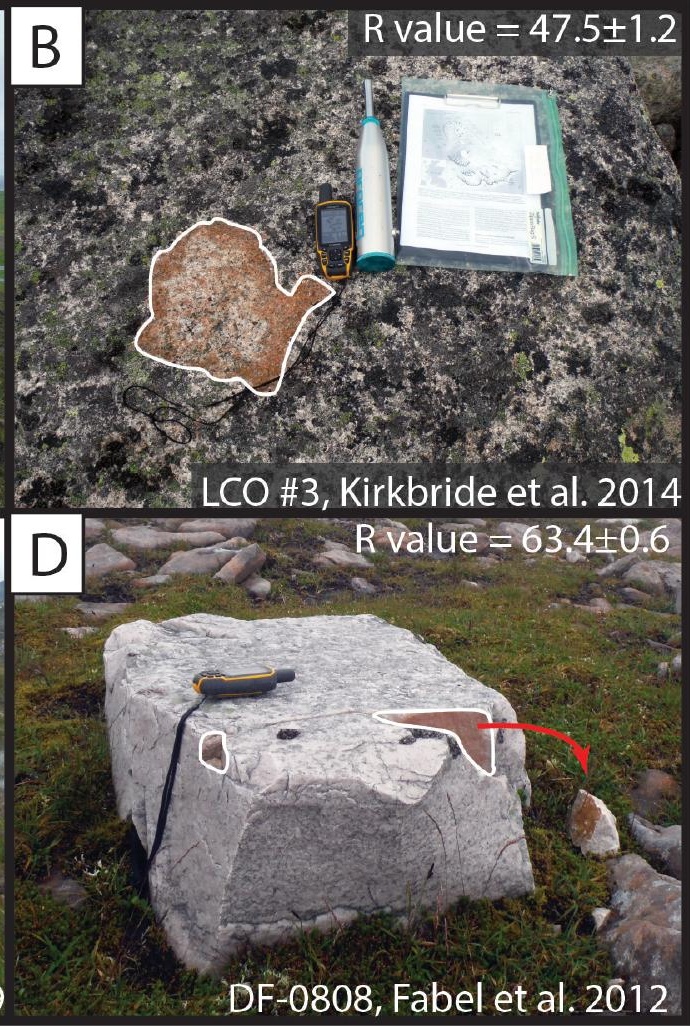

DF-0808, Fabel et al. 2012 

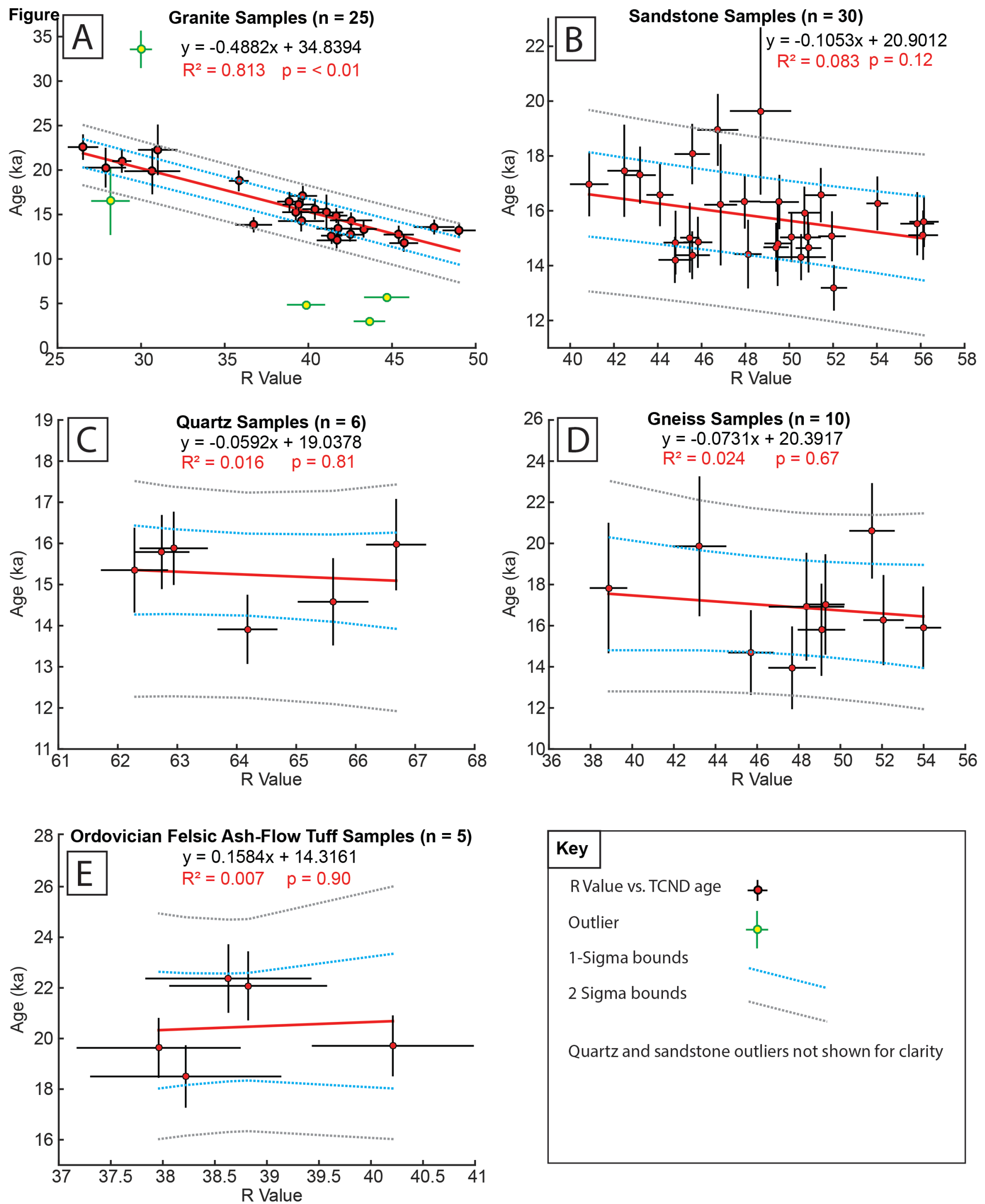


\section{Figure}
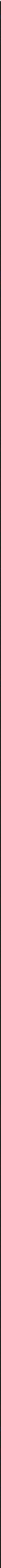
SHED ages

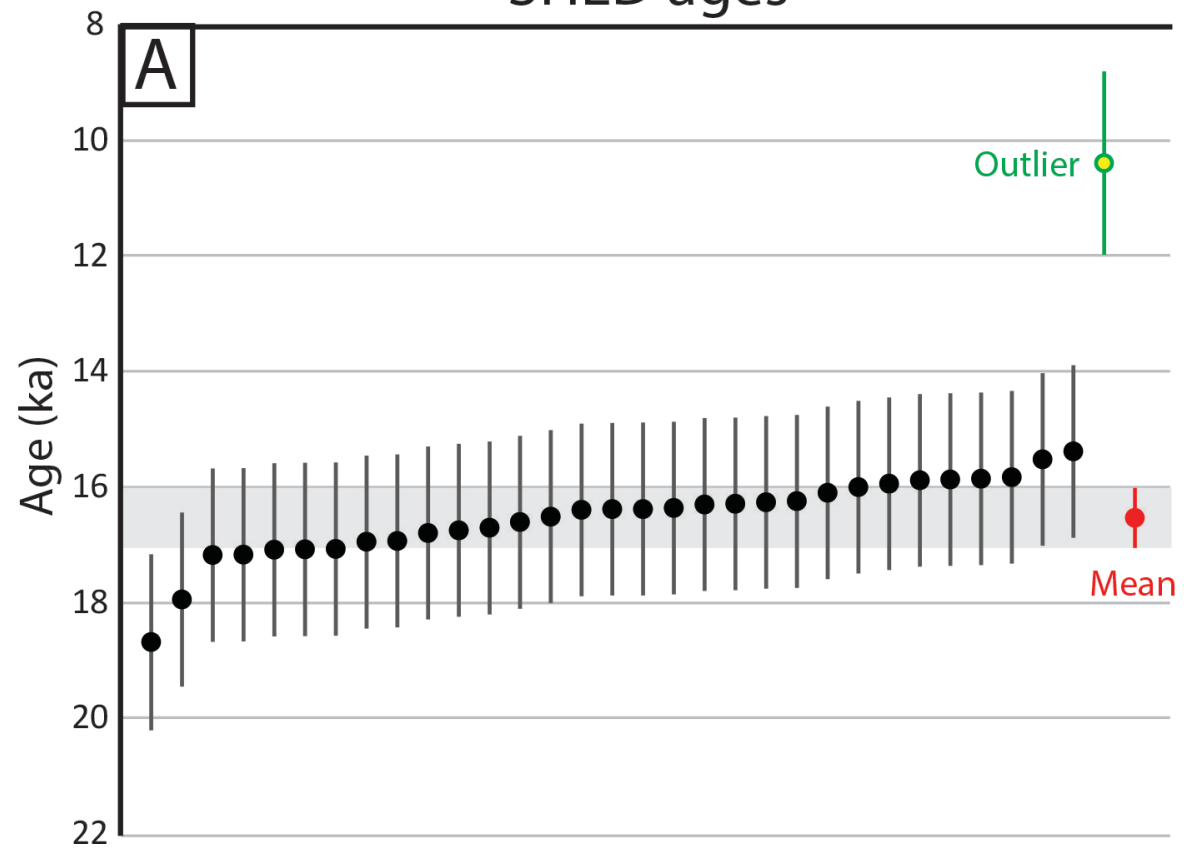

Age comparison

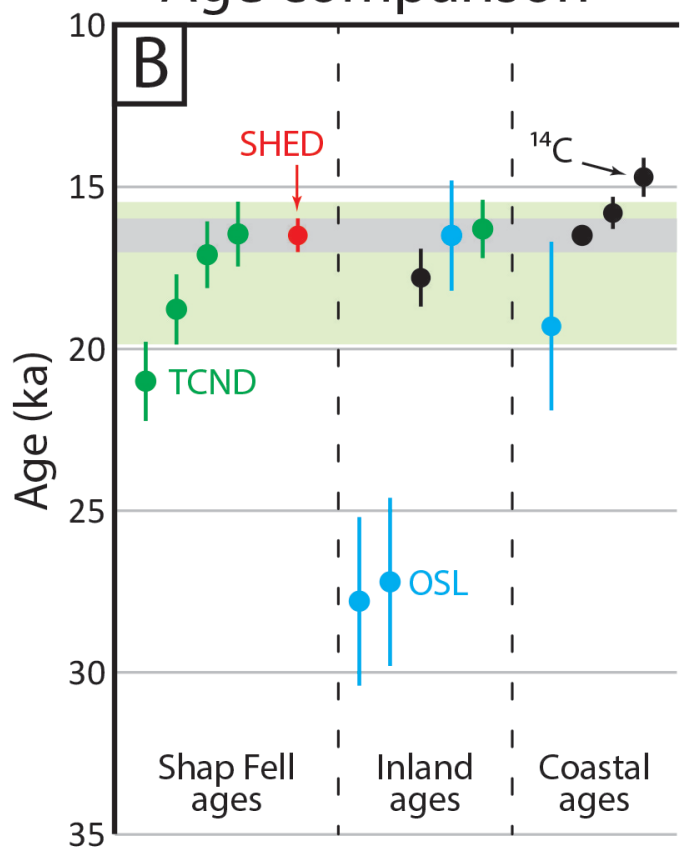


Table-1: Schmidt hammer sample methods arranged by year. This list is compiled from Goudie, (2006); Niedzielski et al. (2009) and Özkan \& Bilim (2008).

Authors

Hucka (1965)

Deere \& Miller (1966)

Soiltest (1976)

Fowell \& McFeat Smith (1976)

Day \& Goudie (1977)

ISRM (1978); Young \& Fowell (1978)

Selby (1980)

Kazi \& Al-Mansour (1980)

Poole \& Farmer (1980)

Williams \& Robinson (1983)

Matthews \& Shakesby (1984)

Matthews et al. (1986); Winkler (2005); Shakesby et al. (2006)

Ballantyne et al. (1990)

Hall (1993)

Goktan \& Ayday (1993)

Matsukura \& Matsuoka (1996)

Mellor et al., (1997)

White et al. (1998)

USBR (1998)

Katz et al., (2000)

Matsukura \& Tanaka (2000)

Goudie et al. (2002)

Sumner \& Nel (2002)

Ericson (2004)

Engel (2007)

Migoń \& Placek (2007)

Owen et al., (2007)
Test Procedure

Select the peak rebound value from 10 continuous impacts at a point.

Average the peaks of the three sets of tests conducted at three separate points

Record three readings along the length of an Nxsize core for each 451

rotation. Average a total of 24 readings, diregarding the erroneous readings

Record 15 rebound values from single impacts and average the highest

10. The maximum deviationshould be less than 2.5

Mean of the last 5 values from 10 continuous impacts at a point

10 or 15 impacts, a greater sample size may be desirable if the material is highly variable

20 rebound values from single impacts separated by at least a plunger diameter and average the upper 10 values

25 impacts at each site

Record at least 35 rebound readings, drop the 10 lowest readings and average the remaining 25

Select the peak rebound value from 5 continuous impacts at a point.

Average the peaks of the three sets of tests conducted at three separate points

5 readings on each of 20 blocks

15 rebound values for each sample, with 5 values that deviate most from the mean being discarded

50 boulders; one blow per boulder

5 readings at 5 points on 20 boulders at a site

A minimum of 100 values for each side of a dyke

Record 20 rebound values from single impacts separated by at least a plunger diameter. Reject outlier values using Cheauvenet's criterion, and average the remaining readings

30 rebounds

9 readings: 3 sample points with 3 readings from the corner of a $5 \mathrm{~cm}$ triangle centred on the point

20 boulders sampled 8 times (i.e. on 8 different faces)

Ten readings at various locations on each surface. Discount the 5 lowest readings and average the highest 5

32-40 individual impacts and averaged the upper 50\%

15 at a site, with the initial $2-3$ omitted

10 readings at each site

Take 15 readings at different points and discard the 5 worst outliers to obtain a mean value from the remaining 10 values

10 readings randomly across $2-3 \mathrm{dm} 2$

25 impacts at each site

40 readings at each site

50 impacts on quartz veins 
Table-2: Details of samples used for SHED calibration with R Values and TCND ages.

\begin{tabular}{|c|c|c|c|c|c|c|c|c|c|c|}
\hline $\begin{array}{c}\text { Sample } \\
\text { Name }\end{array}$ & Publication & Location (N/W) & $\begin{array}{c}\text { Bedrock/ } \\
\text { Erratic }\end{array}$ & $\begin{array}{c}\text { Altitude } \\
\text { (m) }\end{array}$ & Lithology & R Value & Uncertainty & Age (ka) & Uncertainty & Accepted? \\
\hline RM-03 & \multirow{16}{*}{$\begin{array}{c}\text { Ballantyne et al ., } \\
\text { 2009a }\end{array}$} & $57.63158,-5.66000$ & Erratic & 329 & \multirow{16}{*}{ Sandstone } & 50.69 & 0.70 & 15.9 & 0.9 & $\checkmark$ \\
\hline RM-02 & & $57.63157,-5.65985$ & Erratic & 333 & & 50.85 & 0.55 & 15.0 & 0.9 & $\checkmark$ \\
\hline RM-01 & & $57.63088,-5.65043$ & Erratic & 345 & & 56.11 & 0.64 & 15.1 & 0.9 & $\checkmark$ \\
\hline GM-06 & & $57.78719,-5.70969$ & Erratic & 223 & & 50.10 & 0.48 & 15.0 & 0.9 & $\checkmark$ \\
\hline GM-03 & & $57.76403,-5.72199$ & Erratic & 130 & & 47.97 & 0.67 & 16.3 & 1.0 & $\checkmark$ \\
\hline GM-02 & & $57.76213,-5.73453$ & Erratic & 101 & & 44.78 & 0.71 & 14.2 & 0.8 & $\checkmark$ \\
\hline BR-05 & & $57.85526,-5.70468$ & Bedrock & 106 & & 54.02 & 0.46 & 16.3 & 1.0 & $\checkmark$ \\
\hline BR-04 & & $57.85479,-5.70511$ & Bedrock & 96 & & 43.19 & 0.68 & 17.3 & 1.0 & $\checkmark$ \\
\hline BR-03 & & $57.85481,-5.70519$ & Bedrock & 93 & & 45.57 & 0.77 & 18.1 & 1.1 & $\checkmark$ \\
\hline AM-05 & & $57.50681,-5.74867$ & Erratic & 255 & & 49.55 & 0.85 & 16.3 & 1.0 & $\checkmark$ \\
\hline AM-04 & & $57.50669,-5.74964$ & Erratic & 255 & & 45.83 & 0.62 & 14.8 & 0.9 & $\checkmark$ \\
\hline AM-03 & & $57.50697,-5.74968$ & Erratic & 255 & & 45.57 & 0.77 & 14.4 & 0.8 & $\checkmark$ \\
\hline AM-01 & & $57.50642,-5.74929$ & Erratic & 259 & & 50.54 & 1.09 & 14.3 & 0.8 & $\checkmark$ \\
\hline AC-03 & & $57.98310,-5.26063$ & Erratic & 325 & & 49.40 & 0.54 & 14.7 & 0.9 & $\checkmark$ \\
\hline AC-02 & & $57.98536,-5.26284$ & Erratic & 335 & & 50.88 & 0.55 & 14.6 & 0.9 & $\checkmark$ \\
\hline AC-01 & & $57.98542,-5.26306$ & Erratic & 333 & & 51.95 & 0.59 & 15.1 & 0.9 & $\checkmark$ \\
\hline LV0603 & \multirow{3}{*}{$\begin{array}{l}\text { Bradwell et al ., } \\
2008\end{array}$} & $58.12391,-4.98157$ & Erratic & 101 & \multirow{3}{*}{ Quartz } & 62.28 & 0.55 & 15.3 & 1.0 & $\checkmark$ \\
\hline LV0602 & & $58.12379,-4.98118$ & Erratic & 105 & & 65.62 & 0.58 & 14.6 & 1.0 & $\checkmark$ \\
\hline LV0601 & & $58.12404,-4.98179$ & Erratic & 102 & & 66.68 & 0.49 & 16.0 & 1.1 & $\checkmark$ \\
\hline CE9 & \multirow{6}{*}{$\begin{array}{c}\text { Everest \& Kubik, } \\
2006\end{array}$} & $57.09855,-3.80015$ & Erratic & 618 & \multirow{6}{*}{ Granite } & 34.47 & 0.63 & 16.0 & 1.2 & $x^{d}$ \\
\hline CE8 & & $57.09830,-3.80012$ & Erratic & 617 & & 35.13 & 0.70 & 14.3 & 1.2 & $x^{d}$ \\
\hline CE4 & & $57.13184,-3.77971$ & Erratic & 421 & & 35.16 & 0.63 & 16.7 & 1.6 & $x^{d}$ \\
\hline CE3 & & $57.12981,-3.78208$ & Erratic & 457 & & 39.57 & 0.81 & 16.9 & 1.1 & $x^{d}$ \\
\hline CE2 & & $57.12924,-3.78420$ & Erratic & 479 & & 36.31 & 0.82 & 15.2 & 1.3 & $x^{d}$ \\
\hline CE1 & & $57.13185,-3.78143$ & Erratic & 422 & & 36.00 & 0.60 & 16.1 & 1.2 & $x^{d}$ \\
\hline WRR/8 & \multirow{4}{*}{$\begin{array}{l}\text { Everest } \text { et al ., } \\
\quad 2006\end{array}$} & $57.76021,-5.73915$ & Erratic & 84 & \multirow{4}{*}{ Gneiss } & 47.68 & 1.10 & 14.0 & 2.0 & $\checkmark$ \\
\hline WRR/7 & & $57.75983,-5.73964$ & Erratic & 80 & & 43.23 & 1.25 & 19.9 & 3.4 & $\checkmark$ \\
\hline WRR/6 & & $57.75990,-5.73977$ & Erratic & 79 & & 38.86 & 0.86 & 17.8 & 3.1 & $\checkmark$ \\
\hline WRR/4 & & $57.75019,-5.74571$ & Erratic & 80 & & 48.37 & 1.77 & 16.9 & 2.6 & $\checkmark$ \\
\hline DF-0815 & \multirow{4}{*}{ Fabel et al ., 2012} & $57.51209,-5.40122$ & Erratic & 915 & \multirow{2}{*}{ Sandstone } & 56.15 & 0.63 & 15.6 & 0.9 & $\checkmark$ \\
\hline DF-0814 & & $57.51197,-5.40145$ & Erratic & 917 & & 51.44 & 0.68 & 16.6 & 1.0 & $\checkmark$ \\
\hline DF-0809 & & $57.48858,-5.46339$ & Erratic & 835 & \multirow{2}{*}{ Quartz } & 64.18 & 0.49 & 13.9 & 0.8 & $\checkmark$ \\
\hline DF-0808 & & $57.48865,-5.46426$ & Erratic & 838 & & 63.39 & 0.61 & 39.0 & 2.1 & $x^{a}$ \\
\hline
\end{tabular}

${ }^{\mathrm{a}}$ Inherited, ${ }^{\mathrm{b}}$ Transient shielding or site disturbance, ${ }^{\mathrm{c}}$ Overturning, ${ }^{\mathrm{d}}$ Quartz phenocrysts, ${ }^{\mathrm{e}}$ Glacially polished, ${ }^{\mathrm{f}}$ Anomolously soft 
Table-2 continued:

\begin{tabular}{|c|c|c|c|c|c|c|c|c|c|c|}
\hline $\begin{array}{l}\text { Sample } \\
\text { Name }\end{array}$ & Publication & Location (N/W) & $\begin{array}{l}\text { Bedrock/ } \\
\text { Erratic }\end{array}$ & $\begin{array}{c}\text { Altitude } \\
\text { (m) }\end{array}$ & Lithology & R Value & Uncertainty & Age (ka) & Uncertainty & Accepted? \\
\hline DF-0807 & \multirow{6}{*}{ Fabel et al., 2012} & $57.48851,-5.46355$ & Bedrock & 837 & \multirow{2}{*}{ Sandstone } & 49.47 & 0.57 & 14.8 & 1.5 & $\checkmark$ \\
\hline DF-0806 & & $57.48870,-5.46476$ & Bedrock & 844 & & 52.04 & 0.56 & 13.2 & 0.8 & $\checkmark$ \\
\hline DF-0805 & & $57.49104,-5.46532$ & Erratic & 929 & \multirow{4}{*}{ Quartz } & 59.69 & 0.65 & 50.7 & 2.7 & $x^{a}$ \\
\hline DF-0804 & & $57.49150,-5.46400$ & Erratic & 918 & & 62.74 & 0.45 & 15.8 & 0.9 & $\checkmark$ \\
\hline DF-0803 & & $57.49209,-5.46437$ & Erratic & 918 & & 62.94 & 0.56 & 15.9 & 0.9 & $\checkmark$ \\
\hline DF-0801 & & $57.49171,-5.46310$ & Erratic & 906 & & 62.74 & 0.54 & 63.1 & 3.4 & $x^{a}$ \\
\hline AF04 & \multirow{5}{*}{$\begin{array}{l}\text { Glasser et al ., } \\
2012\end{array}$} & $52.77397,-3.69943$ & Bedrock & 639 & \multirow{5}{*}{$\begin{array}{l}\text { Ordovician felsic } \\
\text { ash-flow tuffs }\end{array}$} & 38.22 & 0.91 & 18.5 & 1.2 & $\checkmark$ \\
\hline AF03 & & $52.78718,-3.68809$ & Bedrock & 903 & & 38.82 & 0.75 & 22.1 & 1.3 & $\checkmark$ \\
\hline AF02 & & $52.78302,-3.69214$ & Bedrock & 880 & & 38.63 & 0.79 & 22.4 & 1.3 & $\checkmark$ \\
\hline AF01 & & $52.78154,-3.69035$ & Bedrock & 816 & & 40.21 & 0.77 & 19.7 & 1.2 & $\checkmark$ \\
\hline AB01 & & $52.80182,-3.68454$ & Bedrock & 878 & & 37.96 & 0.78 & 19.6 & 1.1 & $\checkmark$ \\
\hline LCO \#6 & \multirow{12}{*}{$\begin{array}{l}\text { Kirkbride } \text { et al ., } \\
2014\end{array}$} & $57.10913,-3.68461$ & Erratic & 895 & \multirow{12}{*}{ Granite } & 39.25 & 0.76 & 15.3 & 0.8 & $\checkmark$ \\
\hline LCO \#5 & & $57.10909,-3.68562$ & Erratic & 898 & & 36.73 & 1.05 & 13.8 & 0.8 & $\checkmark$ \\
\hline LCO \#4 & & $57.10875,-3.68435$ & Erratic & 906 & & 39.57 & 1.33 & 14.3 & 1.1 & $\checkmark$ \\
\hline LCO \#3 & & $57.10859,-3.68351$ & Erratic & 915 & & 47.52 & 1.16 & 13.6 & 0.7 & $\checkmark$ \\
\hline LCO \#2 & & $57.10815,-3.68317$ & Erratic & 928 & & 49.01 & 0.94 & 13.2 & 0.7 & $\checkmark$ \\
\hline LCO \#1 & & $57.10920,-3.68513$ & Erratc & 898 & & 39.41 & 0.90 & 16.1 & 0.8 & $\checkmark$ \\
\hline LCI \#6 & & $57.10858,-3.68500$ & Erratic & 905 & & 42.55 & 1.21 & 14.3 & 0.8 & $\checkmark$ \\
\hline LCI \#5 & & $57.10789,-3.68443$ & Erratic & 911 & & 39.86 & 1.09 & 4.9 & 0.3 & $x^{c}$ \\
\hline LCI \#4 & & $57.10867,-3.68498$ & Erratic & 902 & & 42.49 & 0.79 & 12.7 & 0.7 & $\checkmark$ \\
\hline LCI \#3 & & $57.10748,-3.68256$ & Erratic & 928 & & 41.79 & 1.26 & 13.4 & 0.7 & $\checkmark$ \\
\hline LCI \#2 & & $57.10830,-3.68414$ & Erratic & 909 & & 44.68 & 1.30 & 5.7 & 0.3 & $x^{c}$ \\
\hline LCI \#1 & & $57.10834,-3.68425$ & Erratic & 910 & & 43.65 & 0.89 & 3.0 & 0.2 & $x^{c}$ \\
\hline WH2 & \multirow{10}{*}{$\begin{array}{l}\text { Phillips et al ., } \\
2008\end{array}$} & $58.89154,-3.36132$ & Erratic & 342 & \multirow{2}{*}{ Sandstone } & 38.11 & 0.47 & 35.6 & 2.2 & $x^{a}$ \\
\hline WH1 & & $58.90318,-3.33989$ & Erratic & 446 & & 27.64 & 0.48 & 19.7 & 1.2 & $x^{f}$ \\
\hline PF5 & & $57.24349,-2.55792$ & Bedrock & 384 & \multirow{4}{*}{ Granite } & 27.88 & 1.17 & 20.3 & 2.1 & $\checkmark$ \\
\hline PF4 & & $57.24343,-2.55800$ & Erratic & 384 & & 30.67 & 1.62 & 19.9 & 2.5 & $\checkmark$ \\
\hline PF3 & & $57.24328,-2.55800$ & Bedrock & 385 & & 31.00 & 1.13 & 22.3 & 2.7 & $\checkmark$ \\
\hline PF1 & & $57.24342,-2.55806$ & Erratic & 383 & & 28.17 & 1.10 & 16.5 & 3.7 & $x^{b}$ \\
\hline ORK4 & & $58.96765,-3.30502$ & Bedrock & 94 & \multirow{4}{*}{ Gneiss } & 45.70 & 1.05 & 14.7 & 2.0 & $\checkmark$ \\
\hline ORK3 & & $58.96768,-3.30511$ & Bedrock & 92 & & 49.28 & 0.88 & 17.0 & 2.4 & $\checkmark$ \\
\hline ORK2 & & $58.96772,-3.30520$ & Erratic & 94 & & 51.52 & 1.05 & 20.6 & 2.3 & $\checkmark$ \\
\hline ORK1 & & $58.96772,-3.30570$ & Erratic & 88 & & 53.98 & 0.82 & 15.9 & 2.0 & $\checkmark$ \\
\hline
\end{tabular}

${ }^{\mathrm{a}}$ Inherited, ${ }^{\mathrm{b}}$ Transient shielding or site disturbance, ${ }^{\mathrm{c}}$ Overturning, ${ }^{\mathrm{d}}$ Quartz phenocrysts, ${ }^{\mathrm{e}} \overline{\text { Glacially polished, }}{ }^{\mathrm{f}}$ Anomolously soft 


\begin{tabular}{|c|c|c|c|c|c|c|c|c|c|c|}
\hline $\begin{array}{l}\text { Sample } \\
\text { Name }\end{array}$ & Publication & Location (N/W) & $\begin{array}{c}\text { Bedrock/ } \\
\text { Erratic }\end{array}$ & $\begin{array}{c}\text { Altitude } \\
\text { (m) }\end{array}$ & Lithology & R Value & Uncertainty & Age (ka) & Uncertainty & Accepted? \\
\hline ORK14 & \multirow{15}{*}{ Phillips et al., 2008} & $59.00910,-3.33618$ & Erratic & 97 & \multirow{2}{*}{ Gneiss } & 52.07 & 0.93 & 16.3 & 2.2 & $\checkmark$ \\
\hline ORK13 & & $59.00840,-3.33670$ & Erratic & 102 & & 49.09 & 1.10 & 15.8 & 2.2 & $\checkmark$ \\
\hline ORK12 & & $59.01373,-3.33193$ & Erratic & 64 & \multirow{2}{*}{ Sandstone } & 46.87 & 0.71 & 16.2 & 2.2 & $\checkmark$ \\
\hline ORK11 & & $59.01318,-3.33066$ & Erratic & 61 & & 43.53 & 0.43 & 13.5 & 1.8 & $x^{b}$ \\
\hline CAITH9 & & $58.65741,-3.38211$ & Bedrock & 89 & \multirow{9}{*}{ Sandstone } & 42.47 & 0.73 & 17.5 & 1.6 & $\checkmark$ \\
\hline CAITH8 & & $58.32618,-3.19616$ & Erratic & 84 & & 40.87 & 0.84 & 17.0 & 1.1 & $\checkmark$ \\
\hline CAITH7 & & $58.32618,-3.19687$ & Bedrock & 84 & & 55.84 & 0.73 & 15.5 & 1.1 & $\checkmark$ \\
\hline CAITH6 & & $58.32627,-3.19702$ & Erratic & 79 & & 39.56 & 1.26 & 13.3 & 1.1 & $x^{b}$ \\
\hline CAITH5 & & $58.32618,-3.19620$ & Bedrock & 79 & & 50.86 & 0.76 & 12.1 & 1.2 & $x^{b}$ \\
\hline CAITH13 & & $58.35656,-3.19412$ & Erratic & 131 & & 46.74 & 0.90 & 18.9 & 1.3 & $\checkmark$ \\
\hline CAITH12 & & $58.36465,-3.18856$ & Bedrock & 164 & & 48.69 & 1.36 & 19.6 & 3.0 & $\checkmark$ \\
\hline CAITH11 & & $58.66029,-3.38128$ & Erratic & 108 & & 44.10 & 0.58 & 16.6 & 1.1 & $\checkmark$ \\
\hline CAITH10 & & $58.66076,-3.38053$ & Erratic & 110 & & 44.16 & 0.38 & 61.3 & 3.8 & $x^{a}$ \\
\hline BEN4 & & $57.29250,-2.56062$ & Bedrock & 531 & \multirow{2}{*}{ Granite } & 26.53 & 0.86 & 22.6 & 1.3 & $\checkmark$ \\
\hline BEN3 & & $57.29244,-2.56153$ & Bedrock & 524 & & 29.99 & 0.61 & 33.6 & 2.0 & $x^{a}$ \\
\hline STR05-08 & \multirow{10}{*}{ Small et al ., 2012} & $57.27057,-6.00919$ & Erratic & 147 & \multirow{10}{*}{ Granite } & 41.08 & 0.96 & 15.2 & 1.9 & $\checkmark$ \\
\hline STR04-08 & & $57.27053,-6.00871$ & Erratic & 147 & & 41.67 & 0.61 & 14.9 & 0.7 & $\checkmark$ \\
\hline STR03-08 & & $57.26892,-6.00708$ & Erratic & 201 & & 47.27 & 0.88 & 16.0 & 1.2 & $x^{e}$ \\
\hline STR02-08 & & $57.26899,-6.00717$ & Erratic & 198 & & 40.39 & 0.70 & 15.6 & 1.1 & $\checkmark$ \\
\hline STR01-08 & & $57.26840,-6.00664$ & Erratic & 207 & & 54.38 & 1.36 & 15.7 & 0.9 & $x^{e}$ \\
\hline SLAP-5 & & $57.19839,-6.00131$ & Erratic & 23 & & 45.70 & 0.81 & 11.8 & 0.9 & $\checkmark$ \\
\hline SLAP-4 & & $57.19812,-6.00149$ & Erratic & 21 & & 41.39 & 0.58 & 12.6 & 0.8 & $\checkmark$ \\
\hline SLAP-3 & & $57.19868,-6.00110$ & Erratic & 26 & & 41.69 & 1.14 & 12.1 & 0.8 & $\checkmark$ \\
\hline SLAP-2 & & $57.19865,-6.00110$ & Erratic & 26 & & 45.40 & 0.85 & 12.7 & 0.9 & $\checkmark$ \\
\hline SLAP-1 & & $57.19865,-6.00111$ & Erratic & 26 & & 43.30 & 0.74 & 13.4 & 0.9 & $\checkmark$ \\
\hline AT-3 & \multirow{3}{*}{ Stone et al ., 1998} & $57.82861,-5.23541$ & Bedrock & 611 & \multirow{3}{*}{ Sandstone } & 48.12 & 0.58 & 14.4 & 1.2 & $\checkmark$ \\
\hline AT-2 & & $57.82940,-5.23432$ & Bedrock & 609 & & 44.81 & 0.51 & 14.8 & 1.1 & $\checkmark$ \\
\hline $\mathrm{AT}-1$ & & $57.83052,-5.23368$ & Bedrock & 607 & & 45.46 & 0.40 & 15.0 & 1.2 & $\checkmark$ \\
\hline SHAP-08 & \multirow{4}{*}{$\begin{array}{l}\text { Wilson et al ., } \\
\qquad 2013 \mathrm{c}\end{array}$} & $54.47993,-2.61753$ & Erratic & 330 & \multirow{4}{*}{ Granite } & 28.85 & 0.52 & 21.0 & 1.2 & $\checkmark$ \\
\hline SHAP-07 & & $54.49098,-2.61322$ & Erratic & 325 & & 38.87 & 0.68 & 16.5 & 1.0 & $\checkmark$ \\
\hline SHAP-03 & & $54.48643,-2.63406$ & Erratic & 220 & & 35.84 & 0.54 & 18.8 & 1.1 & $\checkmark$ \\
\hline SHAP-02 & & $54.48320,-2.63761$ & Erratic & 280 & & 39.67 & 0.80 & 17.1 & 1.0 & $\checkmark$ \\
\hline
\end{tabular}

${ }^{\mathrm{a}}$ Inherited, ${ }^{\mathrm{b}}$ Transient shielding or site disturbance, ${ }^{\mathrm{c}}$ Overturning, ${ }^{\mathrm{d}}$ Quartz phenocrysts, ${ }^{\mathrm{e}}$ Glacially polished, ${ }^{\mathrm{f}}$ Anomolously soft 
Table-3: Linear regression and significance of $R$ Value calibration for each lithology

\begin{tabular}{ccccc}
\hline Lithology & Number of samples & $\mathrm{R}^{2}$ & Regression & p value \\
\hline Granite & 25 & 0.81 & $-0.4882 \mathrm{x}+34.8394$ & $<0.01$ \\
Sandstone & 30 & 0.08 & $-0.1053 \mathrm{x}+20.9012$ & 0.12 \\
Quartz & 6 & 0.02 & $-0.0592 \mathrm{x}+19.0378$ & 0.81 \\
Gneiss & 10 & 0.02 & $-0.0731 \mathrm{x}+20.3917$ & 0.67 \\
Ordovician felsic ash-flow tuffs & 5 & 0.01 & $0.1584 \mathrm{x}+14.3161$ & 0.90 \\
\hline
\end{tabular}


Table-4: Sample location, R Values, and calibrated SHED ages for SHAP area samples.

\begin{tabular}{|c|c|c|c|c|c|c|c|c|}
\hline $\begin{array}{c}\text { Sample } \\
\text { Name } \\
\end{array}$ & Location (N/W) & Sample type & $\begin{array}{c}\text { Altitude } \\
(\mathbf{m})\end{array}$ & R Value & $\begin{array}{l}\text { Uncer } \\
\text { tainty }\end{array}$ & $\begin{array}{c}\text { Sample } \\
\text { type }\end{array}$ & Age (ka) & $\begin{array}{l}\text { Uncer } \\
\text { tainty }\end{array}$ \\
\hline${ }^{\mathrm{a}} \mathrm{CR}-1$ & $54.51377,-2.58928$ & Erratic & 221 & 50.50 & 0.94 & SHED & 10.4 & 1.6 \\
\hline CR-2 & $54.51384,-2.58917$ & Erratic & 219 & 33.17 & 0.88 & SHED & 18.6 & 1.5 \\
\hline CR-3 & $54.51392,-2.58910$ & Erratic & 217 & 36.76 & 0.86 & SHED & 16.9 & 1.5 \\
\hline CR-4 & $54.51355,-2.58822$ & Erratic & 213 & 36.44 & 0.84 & SHED & 17.0 & 1.5 \\
\hline CR-5 & $54.51358,-2.58792$ & Erratic & 214 & 37.42 & 0.78 & SHED & 16.6 & 1.5 \\
\hline CR-6 & $54.51454,-2.58748$ & Erratic & 210 & 38.46 & 0.88 & SHED & 16.1 & 1.5 \\
\hline CR-7 & $54.51458,-2.58746$ & Erratic & 208 & 39.01 & 0.86 & SHED & 15.8 & 1.5 \\
\hline CR-8 & $54.51448,-2.58776$ & Erratic & 209 & 38.05 & 0.74 & SHED & 16.3 & 1.5 \\
\hline CR-9 & $54.51443,-2.58789$ & Erratic & 208 & 37.88 & 0.79 & SHED & 16.3 & 1.5 \\
\hline CR-10 & $54.51454,-2.58821$ & Erratic & 206 & 36.46 & 0.84 & SHED & 17.0 & 1.5 \\
\hline CR-11 & $54.51461,-2.58833$ & Erratic & 207 & 38.93 & 0.82 & SHED & 15.8 & 1.5 \\
\hline CR-12 & $54.51461,-2.58856$ & Erratic & 206 & 36.47 & 0.82 & SHED & 17.0 & 1.5 \\
\hline CR-13 & $54.51469,-2.58862$ & Erratic & 207 & 38.13 & 0.74 & SHED & 16.2 & 1.5 \\
\hline CR-14 & $54.51483,-2.58849$ & Erratic & 208 & 38.96 & 0.89 & SHED & 15.8 & 1.5 \\
\hline CR-15 & $54.51484,-2.58848$ & Erratic & 208 & 37.89 & 0.89 & SHED & 16.3 & 1.5 \\
\hline CR-16 & $54.51488,-2.58839$ & Erratic & 210 & 36.72 & 0.77 & SHED & 16.9 & 1.5 \\
\hline CR-17 & 54.51493. -2.58833 & Erratic & 208 & 37.62 & 0.70 & SHED & 16.5 & 1.5 \\
\hline CR-18 & $54.51493,-2.58818$ & Erratic & 208 & 36.27 & 0.84 & SHED & 17.1 & 1.5 \\
\hline CR-19 & $54.51473,-2.58806$ & Erratic & 208 & 38.07 & 0.94 & SHED & 16.3 & 1.5 \\
\hline CR-20 & $54.51476,-2.58823$ & Erratic & 209 & 37.04 & 0.77 & SHED & 16.8 & 1.5 \\
\hline CR-21 & $54.51468,-2.58835$ & Erratic & 210 & 34.68 & 0.64 & SHED & 17.9 & 1.5 \\
\hline CR-22 & $54.51467,-2.58826$ & Erratic & 210 & 36.26 & 0.57 & SHED & 17.1 & 1.5 \\
\hline CR-23 & $54.51464,-2.58820$ & Erratic & 209 & 37.13 & 0.72 & SHED & 16.7 & 1.5 \\
\hline CR-24 & $54.51463,-2.58807$ & Erratic & 210 & 37.86 & 0.86 & SHED & 16.4 & 1.5 \\
\hline CR-25 & $54.51453,-2.58794$ & Erratic & 211 & 38.66 & 0.88 & SHED & 16.0 & 1.5 \\
\hline CR-26 & $54.51463,-2.58764$ & Erratic & 211 & 38.16 & 0.84 & SHED & 16.2 & 1.5 \\
\hline CR-27 & $54.51470,-2.58752$ & Erratic & 212 & 37.92 & 0.92 & SHED & 16.3 & 1.5 \\
\hline CR-28 & $54.51481,-2.58777$ & Erratic & 213 & 38.79 & 0.85 & SHED & 15.9 & 1.5 \\
\hline CR-29 & $54.51491,-2.58754$ & Erratic & 215 & 37.22 & 0.83 & SHED & 16.7 & 1.5 \\
\hline CR-30 & $54.51490,-2.58748$ & Erratic & 215 & 38.91 & 0.92 & SHED & 15.8 & 1.5 \\
\hline CR-31 & $54.51509,-2.58789$ & Erratic & 214 & 39.93 & 0.90 & SHED & 15.3 & 1.5 \\
\hline CR-32 & $54.53400,-2.64785$ & Erratic & 295 & 39.65 & 0.79 & SHED & 15.5 & 1.5 \\
\hline OxL-1802 & $54.077,-2.136$ & Sediment & 365 & N/A & N/A & $\mathrm{OSL}^{\mathrm{b}}$ & 16.5 & 1.7 \\
\hline OxL-1806 & $54.147,-2.775$ & Sediment & 103 & N/A & N/A & $\mathrm{OSL}^{\mathrm{b}}$ & 19.3 & 2.6 \\
\hline OxL-1790 & $54.117,-2.071$ & Sediment & 365 & N/A & N/A & $\mathrm{OSL}^{\mathrm{b}}$ & 27.8 & 2.6 \\
\hline OxL-1789 & $54.117,-2.071$ & Sediment & 365 & N/A & N/A & $\mathrm{OSL}^{\mathrm{b}}$ & 27.2 & 2.6 \\
\hline SHAP-08 & $54.47993,-2.61753$ & Erratic & 330 & N/A & N/A & $\mathrm{TCND}^{\mathrm{c}}$ & 21.01 & 1.22 \\
\hline SHAP-03 & $54.48643,-2.63406$ & Erratic & 220 & N/A & N/A & $\mathrm{TCND}^{\mathrm{c}}$ & 18.78 & 1.08 \\
\hline SHAP-02 & $54.48320,-2.63761$ & Erratic & 280 & N/A & N/A & $\mathrm{TCND}^{\mathrm{c}}$ & 17.09 & 1.03 \\
\hline SHAP-07 & $54.49098,-2.61322$ & Erratic & 325 & N/A & N/A & $\mathrm{TCND}^{\mathrm{c}}$ & 16.45 & 1.00 \\
\hline
\end{tabular}

${ }^{\mathrm{a}}$ Glacially polished; ${ }^{\mathrm{b}}$ data from Telfer et al., 2009; ${ }^{\mathrm{c}}$ data from Wilson et al., 2013c 